\title{
A Novel Ruthenium Fluvastatin Complex Downregulates SNCG Expression to Modulate Breast Carcinoma Cell Proliferation and Apoptosis Via Activating PI3K/Akt/mTOR/VEGF/ MAP Kinase Pathway
}

Wei Liang

Nanjing Medical University Second Affiliated Hospital

Junfeng Shi

Nanjing Medical University Second Affiliated Hospital

Haiyan Xia

Nanjing Medical University Second Affiliated Hospital

Xiaowei Wei ( $\sim$ gswxw@njmu.edu.cn )

Nanjing Medical University Second Affiliated Hospital https://orcid.org/0000-0002-3802-7845

\section{Primary research}

Keywords: chemotherapeutics, antiangiogenic, chemotherapy

Posted Date: August 28th, 2020

DOI: https://doi.org/10.21203/rs.3.rs-65400/v1

License: (c) (i) This work is licensed under a Creative Commons Attribution 4.0 International License. Read Full License

Version of Record: A version of this preprint was published at Oxidative Medicine and Cellular Longevity on June 7th, 2021. See the published version at https://doi.org/10.1155/2021/5537737. 


\section{Abstract}

Background: Breast cancer is the most common cause of malignancy and cancer related morbidity and death worldwide that requests effective and safe chemotherapy. Evaluation of metallo drug based anticancer agents and statins as chemotherapeutics with fewer side effects is largely unexplored research fields

Methods: The synthesis and characterization of Ruthenium fluvastatin complex was achieved using multiple spectroscopic techniques and thus further examined to evaluate its chemotherapeutic prospects in both MDA-MB-231 and MCF-7 cancer lines and eventually in vivo models of DMBA induced mammary carcinogenesis in rodents. The viability of cells was tested using MTT assay. The apoptotic assay in cell lines was analyzed by flow cytometry. Western blot technique and immunohistochemical approach were used to investigate complex induced signaling pathways. TUNEL assay had predicted in-vivo apoptosis.

Results: Our studies indicate that the metal and ligand chelation was materialized by the ligand's functional groups of carbonyl $(=0)$ oxygen and hydroxyl $(-\mathrm{OH})$ and the complex has been observed to be crystalline and able to chelate with CT-DNA. The complex was able to reduce cell proliferation and activate apoptotic events in breast carcinoma cell lines MCF-7 and MDA-MB-231. In addition, the complex was able modify p53 expressions to interfere with apoptosis in the carcinoma of the breast, stimulated by the intrinsic apoptotic path assisted by $\mathrm{Bcl} 2$ and Bax, yet at the same point controlling the PI3K / Akt / mTOR pathway correlated with MMP9 regulated tumor mechanisms.

Conclusion: Our research reveals that ruthenium-fluvastatin chemotherapy may disrupt, rescind or interrupt breast carcinoma progression by modifying intrinsic apoptosis as well as the antiangiogenic cascade, thereby taking the role of a potential candidate in cancer therapy for the immediate future.

\section{Background}

Breast cancer in women is the most recurrent cancer in any of the five continents disgnosed worldwide, with an approximate 2.1 million new cases in 2018 (1). The incident of breast cancer on the Asian continent is still underneath than that of Europe or America, but Asia's participation in the world wide burden of breast cancer is speedily increasing as a result of expressed economic growth and urbanization (2). The situation in China has been alarming partly due to its rapid population growth and socioeconomic development. As a densely populated country, China reports for one fourth of total cancer related death and there has been an increasing incidence in cancer prevalence, mortality rate and emergence among young people (3). China reveals 36.1 percent increase in death rate from 1970-2005 according to numerous breast cancer studies (4). Reports further reveal that, at 2015 in China, the highest rate of breast cancer incidence (127.550 per 100000) was observed in women between 65-69 years of age. In addition, breast cancer incidence rate increased by 69.38\% in 65-69 years age group from 75303 to 127550 per 100000 women in 2005 to 2015 respectively, indicating a yearly average growth of $6.9 \%$ (5). Breast cancer always diagnosed as an invasive malignant tumor without curable therapy (6). Regretfully, the molecular mechanisms underlying breast cancer are still ambiguous to fact. Hence, a good understanding of the genetic underpinnings of breast cancer has great importance and seeking the alteration of researchers for further in-depth study.

Current treatment strategies have limitations which lead to clinical resistance and morbidity associated with therapy due to their side effects and limited efficacy on tumors. Novel molecules are therefore urgently required to combat emerging cases of breast cancer, and with less adverse effects, reduced tumor recurrence and reduced mortality. An interesting approach called drug repurposing in one hand and drug combination approach in another hand to tackle this problem is progressively being investigated and applied $(7,8)$. Addressing the significance, the global market for drug repurposing almost touched nearly 20.7 billion euro in 2015 and is expected to reach 26.6 billion euro by 2020 
(9). Due to advantages like decreased toxicity, better efficacy, decreased dosage at an equal or increased level of efficacy and counter drug resistance, drug combination represent an impressive and progressively used approach which has become a standard for treating cancer (8). Particularly in cancer, various clinical trials are conducted with a crescent focus on the combination of cytotoxic drugs (10). The combination of repurposed pharmaceutical agents with other chemotherapeutic agents continue to show impressive outcomes which are beneficial when traditional monotherapy for cancer patients has failed to provide safe and tolerable treatment (11). To systemically address the concern, this project aim to investigate the effect of drugs like statin with potential to be repurposed for breast cancer therapy, in combination of chemotherapeutic metallodrug like ruthenium.

Statin elicit several effects beyond their lipid reducing roles defined as the pleiotropic effects (12) often caused by blocking the prenylation of a multitude of intracellular signaling proteins and thus affecting the development of cancer among statin user $(13,14,15,16,17)$. Statin has been delineated to be associated with reduced rate of cancer progression and cancer associated mortality $(18,19)$ from gastrointestinal carcinoma $(20,21)$, breast carcinoma $(22)$, hepato-cellular carcinoma (23), prostate cancer (24), lung adenocarcinoma (25) and pancreatic carcinoma (26). Fluvastatin is one of the members of statin family, broadly used as a lipid lowering agent. In addition, to its cholesterol reducing activities, Fluvastatin exhibited the anticancer activities by inducing apoptosis in glioma, breast and hepatocellular carcinoma cell line $(27,28,29)$. Notably, fluvastatin was shown to have a chemo-adjuvant effect on experimental pancreatic cancer (30).

Along with platinum-based cancer drugs, several efforts have been made to design compounds based on ruthenium, since these compounds have reported a lower number of side effects due to their alternate modes of action $(31,32)$. Ruthenium complexes have in many cases exhibited strong cytotoxicity against platinum-resistant tumor cell lines, rendering it as exemplary targets for further investigation $(33,34)$. It may be acknowledged that many rutheniumcontaining compounds including RAPTA-C (35), NAMI-A, and KP1019 (36) have officially managed to reach clinical trials for diverse therapeutic carcinoma management.

Despite advancement in the treatment the high recurrence rate metastasis is associated with poor prognosis of endocrine related cancer (37). Thus a better understanding of the molecular mechanism underlying breast cancer proliferation and metastasis is necessary to identify the potential target for effective therapy. Synucleins are ubiquitously expressed in neuronal cells and abundantly present in presynaptic terminals, and have also been involved in non-neural diseases, especially hormone-responsive breast cancers (38) and ovarian carcinoma (39). Numerous reports have also suggested that SNCG is not expressed in normal and benign breast tissues, but expressed abnormally in a high percentage of advanced and metastatic cancer $(40,41)$ and stimulates hormone dependent growth of breast cancer cells both in vitro and nude mice (42). Research aimed at elucidating the molecular mechanism that trigger the oncogenic function of this protein reported that SNCG expression in the breast cancer cells have developed a more malignant phenotype with increased motility of the cells (38), intensify the activity of transcriptional factor of ERa (43), enhanced resistance to antimicrotubular drugs (39), expedited the microsomal instability (44). Cumulative findings suggest SNCG is a novel unfavorable prognostic marker for breast cancer progression and a potential target for breast cancer treatment. On the basis of this data, the current research uses molecular docking, a widely used bioinformatics technique to evaluate how the molecule of ruthenium fluvastatin binds and interacts with the SNCG target proteins. These in silico methodologies aids towards classifying drug targets through computer-assisted designing that help to i) envision specific active sites for evaluating target structures ii) produce potential molecules that identify the target iii) determine their comparative receptor binding affinities and iv) modify molecules to optimize binding abilities (45). Autodoc is one of many softwares that consists of a series of automatic docking techniques developed to evaluate how molecules attach to a particular targeted protein with a 
preordained arrangement (46). Therefore, our objective is to establish the optimum binding energies of the docked molecules and also to determine the ligand's binding position at the protein binding domain.

A combination of cell proliferation and apoptosis regulates the development of normal breast tissues. Conclusive evidence states that development of cancer is not only a manifestation of unregulated proliferative status along with impaired apoptosis $(47,48)$. In the context of breast cancer, the $\mathrm{Bcl} 2$ gene and the tumor suppressor like p53 genes are thoroughly researched $(49,50)$. Bax and Bcl-2 are indeed the key pro-apoptotic modulators which could additionally improve the PI3K / AKT-related cascade and other pathways related to cell survival and death (51). Furthermore, natural agents may also affect cell migration and invasion of tumor cells by modulating the matrix metalloproteinases (MMPs). Between others, MMP-9 is of particular interest, as patients with increased MMP-9 expression have been identified to end up with poorer diagnosis (52). In addition, breast cancer development includes genetic variations of p53, modified by angiogenic pathway (VEGF), mTOR-related signaling pathway and proapoptotic protein such as Bax corelated with the increased formation of antiapoptotic protein Bcl2 and nuclear proliferating cell antigen (PCNA) $(53,54,55)$.

7,12-Dimethylbenz(a)anthracene may be the most harmful polyaromatic hydrocarbon with the widest environmental application (56). DMBA metabolizes and produces various reactive metabolic intermediates during the carcinogenic cycle, thereby stable DNA adducts formation which are genotoxic and mutagenic that initializing carcinogenic events, close to that in humans (57). The oxidative imbalance influences different types of proteins and genes that modify multiple signaling cascade such as angiogenic process, apoptotic events, cell formation, repairing of DNA, proliferative events and invasion $(58,59)$

Taking all of it into account, we hypothesized and investigated by well-designed experiments in this current study, that ruthenium-fluvastatin could interact with cellular proliferation and induce cell apoptosis by modulating the apoptotic regulators and downstream events such as caspase cascade thus inhibiting the invading and migrating properties of cancer cells. Chemotherapeutic actions in the breast cancer paradigm and the underlying mechanistic approach of the ruthenium - fluvastatin complex have not yet been extensively analyzed. The objective of this project is to synthesize, characterize the ruthenium-fluvastatin complex along with the study of antioxidant status along with DNA binding features and further investigate the chemotherapeutic activity against mammalian cancer in both in vitro and in vivo studies.

\section{Materials And Methods}

\section{Chemicals and Reagents}

The chemicals used for experimental analysis is of pure analytical category. Extra pure methanol, Fluvastatin ((E,3R,5S)-7-[3-(4-fluorophenyl)-1-propan-2-ylindol-2-yl]-3,5-dihydroxyhept-6-enoic acid), TPTZ (2, 4, 6-Tri(2-Pyridyl)-striazine), Ruthenium chloride $\left(\mathrm{RuCl}_{3} . \mathrm{xH}_{2} \mathrm{O}\right)$, highly polymerized CT-DNA (calf thymus DNA), TrisHCl, 7, 12-dimethyl benz (a) anthracene (DMBA), foetal bovine serum (FBS), 3,3'- diaminobenzidine (DAB), proteinase $K$, insulin Lglutamine, sodium pyruvate, streptomycin, penicillin, ABTS (2, 2'-azinobis 3-ethylbenzothiazoline-6-sulphonic acid diammonium salt), streptavidin peroxidase, MTT (3-(4,5- dimethyl thiazole-2-yl)-2,5-diphenyltetrazoliumbromide), DPPH (2, 2 -diphenyl-2-picrylhydrazyl), biotinylated goat anti-rabbit lgG, Annexin $\mathrm{V}$ and propidium iodide (PI) were purchased from Sigma Aldrich Chemical Co (St, Louis, Mo, USA). Antibodies specific for p53, VEGF (627501), Caspase-3, Akt, mTOR, PI3K, pro and active caspase-3 were acquired from Biolegend (Sun Diego, CA, USA). Rabbit anti-rat p53, Bax, Bcl-2, Ki-67, MMP-9and goat anti rabbit IgG secondary antibody were bought from ANASPEC Inc. (San Jose, CA, USA). The MCF- 7 and MDA-MB-231 breast cancer cell line were obtained from American Type Culture 
Collection, 10801 University Boulevard Manassas, VA 20110 USA. Kit diagnosed for apoptosis was purchased from Takara Bio Inc (Japan). Others chemical agents utilized for research purpose were procured from local companies in the finest possible form.

Pharmacophore Analysis

\section{Target protein selection}

The reviewed sequence of human gamma synuclein was retrieved from universal protein sequence database UniProt (http://www.uniprot.org/). The selected protein sequence was used to predict sequence similarity and to predict sequence templates by PSI-BLAST. The specified sequence of template was used to construct three-dimensional protein structures utilizing Swiss model. Using homology modeling by Swiss PDB Viewer assist to envisage the orientation of the protein structure and were validated to check the overall quality of protein and stereochemical activity of atoms and amino acids which were predicted by structural analysis and verification server (SAVES). The conformational complexity of protein structures was used to predict active site amino acids that help for ligand binding using CastP calculation server and the best complex protein structures were used for molecular docking.

\section{Ligand structure design and pharmacophore analysis}

Using ACD / ChemSketch software, chemical structures were designed to add all chemical compositions and the final output was saved in MOL2 format. The training sets were used to predict pharmacophore using molinspiration server and QSAR properties were predicted using Hyperchem. A training set helps to predict the complex polarity and flexibility to examine MM3 force fields to examine the HOMO and LUMO to understand new molecular orbital of individual compounds. The scaffolds were identified and then accelerated screening; a screened pool is focused for bio-targets to inhibit the diseases. Structural screening, fragment-analysis, and pharmacological analyses were used to screen the ligand based on interaction with target apoptotic proteins.

\section{Molecular Docking}

AutoDock 4.6 software was used to predict protein-ligand exchange utilizing different factors such as preparing protein properties, adding Gaussian charges, adding hydrogen atoms with polar amino acid zone, planning ligand molecule with rotatable angle bond interaction, etc.Grid maps of different grid points, centered on the ligands of the complex structure were used for receptors respectively, to cover binding pockets. A set of the Lamarckian genetic algorithm was used for molecular docking simulations. The population size of 150 , the mutation rate of 0.02 , and crossover rate of 0.8 were set as the parameters. Simulations were performed using up to 2.5 million energy evaluations with a maximum of 27000 generations. Each simulation was performed 10 times, yielding 10 docked conformations. The lowest energy conformations were regarded as the binding conformations between the ligands and the proteins. Further, the reverse validation processes ensured that the identified hits really fit the generated Pharmacophore models and active sites of targets. All the parameters required for molecular docking and Pharmacophore mapping were fixed as used in the regular process.

Synthesis of ruthenium Fluvastatin complex

Approximately $433.45 \mathrm{mg}(1 \mathrm{mmol})$ of fluvastatin sodium wasdissolvedin60mlHPLC analytical category ethanol at a room temperature of $27^{\circ} \mathrm{C}$, with continuous mixing using a mechanical stirrer. In another conical flask, approximately $103.5 \mathrm{mg}(0.5 \mathrm{mmol})$ of ruthenium chloride dissolved in $40 \mathrm{ml}$ of ethanol and added dropwise to the fluvastatin solution with continuous stirring for 24 hours. After complete mixing the resultant solution was refluxed at $80^{\circ} \mathrm{C}$ for 3 hours. The reaction mixture was kept in vacuum desiccator over silica gel for seven days. The obtained product was 
brown in color and was found to be soluble in ethanol \& dimethyl sulphoxide (DMSO). (Fig, 1A) represents the possible structure of the ruthenium-fluvastatin complex.

Characterizations of ruthenium-fluvastatin complex

The UV-Visible spectrum of ruthenium-fluvastatin complex and fluvastatin were recorded via UV-1800 Shimadzu double beam spectrophotometer with typical $1.00 \mathrm{~cm}$ quartz cell. FT-IR spectroscopy (ALPHA-T, Bruker, and Rheinstetten, Germany) was used to document the infrared spectrum of the complex over the span of $500-4000 \mathrm{~cm}^{-1}$ wavelength to evaluate the complexation by detecting the metal oxide bond.The molecular structure of the rutheniumfluvastatin complex was studied by employing tandem mass spectrometry (ESI-MS) techniques with electrospray ionization. Molecular ions (m/z) were scanned over a span of 150-1100. A Bruker- Avance-600 MHz spectrometer was used for the studying of the ${ }^{1} \mathrm{H}-\mathrm{NMR}$ spectrum of the complex dissolved in DMSO. Tetra methyl silane (TMS) was used as an internal reference.Scanning electron microscopy (JEOL MAKE, (UK) MODEL- JSM6360) was used to examine the morphological appearance of the sample at an accelerating voltage of $17 \mathrm{kV}$.To examine the surface and morphological features, micrographs were recorded at different magnifications (60X, 200X, 500X, and 1000X). X-ray diffraction (XRD) of the complex was recorded by XPERT-PRO Diffractometer (PANanalytical, Almelo, Netherlands) using X'celerator operating at $40 \mathrm{kV}$ and $30 \mathrm{~mA}$ with Bragg-Brentano geometry with step size 0.033(2】), step time $19.43 \mathrm{~s}$.

Evaluation of antioxidant status of ruthenium fluvastatin complex by DPPH, FRAP, ABTS methods

\section{DPPH assay}

Free radical scavenging ability of the complex was assessed by DPPH radical scavenging assay according to the procedure described by Lim and his co-researcher (60). The hydrogen atom donating ability of the complex was determined by the decolorization of methanol solution of 2,2-diphenyl-1-picrylhydrazyl (DPPH). DPPH produces violet/purple color in methanol solution and fades to shades of yellow color in the presence of antioxidants. Subsequently, $100 \mu \mathrm{l}$ of the complex as well as ligands at different concentrations $(5,10,15,20,25 \mu \mathrm{M})$ were mixed with $0.1 \mathrm{ml}$ of DPPH solution $(0.2 \mathrm{mg} / \mathrm{ml}$ in ethanol) and the absorbance was measured at $515 \mathrm{~nm}$ every 5 minute interval further assessed for 30 minutes $\left(A_{s}\right)$, whereas a solution containing only DPPH functioned as blank $\left(A_{c}\right)$. The percentage of radical scavenging action (RSA \%) was enumerated as

\section{$(\mathrm{RSA} \%)=100\left(\mathrm{~A}_{C}-\mathrm{A}_{S}\right) / \mathrm{A}_{\mathrm{C}}$}

\section{FRAP assay}

The FRAP assay was carried out by method of Benzie and Strain's idea (61) as developed by Griffin and Bhagooli (62). The working FRAP reagent was prepared by mixing 300 mM acetate buffer (pH 3.6), 10 mM 2, 4, 6-tripytidyl-s-triazine (TPTZ) solution and $20 \mathrm{mM} \mathrm{FeCl}_{3} \cdot 6 \mathrm{H}_{2} \mathrm{O}$ at a $10: 1: 1$ ratio prior to use and heated to $37^{\circ} \mathrm{C}$ in a water bath. $3 \mathrm{ml}$ of FRAP reagent was added to $100 \mu$ l of various concentrations $(5-40 \mu \mathrm{M})$ of the complex and ligands. Following reaction, light bluish tint color of the FRAP solution shifted to dark blue and the change in absorbance was detected at wavelength $593 \mathrm{~nm}$ and expressed as $\mathrm{mmol} \mathrm{Fe}^{2+} / \mathrm{g}$ of sample.

\section{ABTS assay}

The radical scavenging activity of ruthenium fluvastatin complex by the ABTS method has been evaluated utilizing the process outlined by Pennycooke and coworkers (63). Following the incorporation of fluvastatin and the complex to 
the ABTS solution (incubated at room temperature for 10-12 minutes) the absorbance was taken at $734 \mathrm{~nm}$. The equation below was used to measure the percentage of radical scavenging action (RSA \%):

Radical Scavenging activity at $750 \mathrm{~nm}(\%)=1-\mathrm{A}_{\mathrm{f}} / \mathrm{A}_{0} 100$.

Where, $A_{0}=$ Absorbance of free radical cation, $A_{f}=$ Absorbance observed 10 min after incorporation of the complex .

DNA Binding assay of ruthenium-fluvastatin complex

CT-DNA intercalation with the complex was calculated using a UV-Visible spectrophotometer (UV-1800 Shimadzu) based on the technique recorded by Dehghan (64). The intrinsic binding constant was calculated as:

$\mathrm{DNA} / \varepsilon_{\mathrm{a}}-\varepsilon_{\mathrm{f}}=\mathrm{DNA} / \varepsilon_{\mathrm{b}}-\varepsilon_{\mathrm{f}}+1 / \mathrm{K}_{\mathrm{b}}\left(\varepsilon_{\mathrm{b}}-\varepsilon_{\mathrm{f}}\right)$

DNA represents the number of base pairing of DNA, $\varepsilon_{a}$ represents the extinction coefficient $\left(A_{o b s} / R u\right)$ factor, $\varepsilon_{f}$ is the free drug related extinction coefficient and $\varepsilon_{\mathrm{b}}$ represents bound drug associated extinction coefficient and complex associated calibration curve is derived from $\varepsilon_{f}$ in the aqueous solution. $\varepsilon_{a}$ represents the ratio of recorded absorbance to concentration of the complex by Beer's law.

In-vitro experimentation

\section{Cell culture}

The breast cancer cell lines MCF-7and MDA-MB-231 were acquired from American Type Culture Collection (ATCC) (Manassas, VA, USA). The tumor cells were normally sustained in DMEM, enriched by $10 \%$ FBS (foetal bovine serum) constituting of antibiotics such as penicillin / streptomycin $(0.5 \mathrm{~mL}-1)$ in an environment of $5 \% \mathrm{CO} 2$ \& $95 \%$ air at $37^{\circ}$ C.

\section{Cell viability assay}

The experiment was assessed by using mitochondrial succinate dehydrogenase to metabolize tetrazolium salts MTT (3-(4, 5 dimethylthiozol-2-yl)-2, 5- diphenyl tetrazolium bromide), which is yellow to produce formazan crystals. The MCF-7 and MDA-MB-231 cells were plated in a $5 \% \mathrm{CO}_{2}$ humidified incubator and exposed to a number of ruthenium fluvastatin doses for 24 hours, containing proper growing media in 96 well plate containing $5.0 \times 10^{3}$ cells for each well and incubated nightly at $37^{\circ} \mathrm{C}$. Upon treatment the medium was withdrawn and MTT solution ( $\left.0.5 \mathrm{mg} / \mathrm{ml}\right) \mathrm{was}$ applied to each well and 3 hours incubated at $37^{\circ} \mathrm{C}$. On a microplate reader, the optical density of solubilised crystals in DMSO was estimated at $560 \mathrm{~nm}$. The cell viability percentage was determined by the equation.

$\%$ viability $=100-\%$ of cytotoxicity

\section{Assessment of apoptotic cells by DAPI staining}

The cell lines were studied for nuclear blebbing and chromatin condensation by staining them with fluorescent nuclear dye 4',6-diamidino-2-phenylindole dihydrochloride (DAPI), using the method developed by Li (65).

\section{Clonogenic assay}

The inhibitory effect of ruthenium-fluvastatin complex on MCF-7 and MDA-MB-231 cells on proliferation was determined by clonogenic assay. The cells were trypsinized to create a single cell suspension and implanted in six well plates with a density of 500 cells / well in $2 \mathrm{ml}$ of medium supplemented with 10\% FBS, kept in a humidified compartment having an atmosphere of $95 \%$ air, $5 \% \mathrm{CO} 2$ at $37{ }^{\circ} \mathrm{C}$. After 24 hours of incubation, culture was replaced 
with fresh media containing three different concentrations of ruthenium fluvastatin complex along with $2 \%$ FBS and cultured for two weeks. After 2 weeks, the cell culture medium was removed and the cells were thoroughly washed with PBS. Cell fixation was done by using $100 \%$ methanol kept at $-20{ }^{\circ} \mathrm{C}$ for 30 minutes. Colonies were stained with $0.5 \%$ crystal violet in $25 \%(\mathrm{v} / \mathrm{v})$ methanol for 1 hour at room temperature. The excess dye was removed by gently rinsing with moderate water flow for 15 minutes. Following washing and drying, the colonies were visually counted to contain > 50 cells / colony. The clonogenicity was measured by the help of the equation below:

Clonogenicity $=($ Cloning number/500x $) \times 100$.

The clonogenic assay was performed in triplicate.

\section{Apoptotic assay by flow cytometry and Cell cycle analysis}

MCF-7 and MDA-MB-231 cells were suspended for cell cycle distribution analysis, and their nuclear DNA was tagged with propidium iodide (PI). Nuclear DNA distribution through the cell cycle process was assessed using a FACS (fluorescence-activated shorter cell). At least 10,000 incidents were obtained and flow-cytometric data collection was carried out using Modfit software, and a histogram of the DNA content against counts was prepared using the methods described by Li (65).

\section{Caspase-3 protein detection by flow cytometry}

MCF-7 and MDA-MB-231cells $\left(5 \times 10^{5}\right.$ cells / well) were cultured on twelve well plate and incubated at $37^{\circ} \mathrm{C}$ in a humidified atmosphere with $5 \% \mathrm{CO}_{2}$ for 24 hour and subsequently treated to three concentrations of ruthenium fluvastatin complex for 24 hours. The cells were again washed properly with ice cold PBS and resuspended with BD Cytofix / Cytoperm Solution (51-6896KC, BD Pharmingen) $400 \mu$ l. The method was initiated by determining the quantity of BD Perm/wash buffer (51-6897KC, BD Pharmingen) and $20 \mu$ of Rabbit anti active caspase 3 polyclonal antibody (351-68655X, BD Pharmingen) was taken, so that each and every individual test was comprise of $100 \mathrm{ml}$ of BD Perm/wash buffer and $20 \mu \mathrm{l}$ of anti active caspase 3 antibody. After incubation on ice for 20 minutes, followed by centrifugation and washing with BD Perm/wash buffer. Subsequently, BD Perm/wash buffer was further added followed by incubation with antibody for thirty minutes at room temperature. Each and every individual tube was further rinsed with $1 \mathrm{ml}$ of BD Perm/wash buffer, centrifuged and then finally added $300 \mu \mathrm{l}$ of BD Perm/wash buffer and analyze by flow cytometry (BD Accuri C6 Plus flow cytometer). Values thus obtained were processed by using FlowJo software.

\section{Western Blot expressions detection of Akt, mTOR, p13K, VEGF, pro Caspase- 3 and Active Caspase-3 proteins}

Western blot analysis detected the expressions Akt, mTOR, p13 K, VEGF, pro Caspase-3 and Active Caspase-3 in cells MCF-7 and MDA-MB-231. The cells were treated for 24 hours after a medium change with three different doses of ruthenium-fluvastatin complex, and maintained for 6 hours. Cell lysates were extracted and equivalent protein amounts were analyzed using SDS-PAGE electrophoresis, followed by a shift to a PVDF (polyvinylidene difluoride) membrane and afterwards blocked to Tris buffer $(25 \mathrm{mM})$ comprising $0.15 \mathrm{M} \mathrm{NaCl}, 0.1$ per cent around 20 and 2-5 per cent non-fat dry milk. At $4{ }^{\circ} \mathrm{C}$ the membranes were cultured with the primary antibodies Akt, mTOR, p13 K, VEGF, pro Caspase-3 and Active Caspase-3 supplemented by a secondary antibody marked with horseradish peroxidase for $1 \mathrm{hr}$. Chemiluminescent (ECL Western Blotting) kit was then used to recognize protein loading against $\beta$ actin (66).

\section{Animal husbandry and maintenance}


Sprague Dawley rat (120-125 gm) of both sexes and 28-day Sprague-Dawley female rats (80-100 grams) were purchased from Nanjing Medical University, Nanjing, China and quarantined even days before experimentation. Animals were housed in a 12-hour light / dark period in polypropylene containers, $22^{\circ} \mathrm{C}\left( \pm 3^{\circ} \mathrm{C}\right)$ at room temperature and nearly 50-58\% humidity. Each animal was fed a semi-purified basal diet and demineralized water ad libitum. The entire animal research process was performed in conjunction with the permission of the Nanjing Medical University's Animal Ethics Committee and the Government's Regulatory Body (IACUS-1912129).

Toxicological studies

\section{Acute oral toxicity study $\left(\mathrm{LD}_{50}\right)$}

oAcute toxicity evaluation of the ruthenium-fluvastatin complex was carried out by incorporating the Recommendations for research on chemicals by the Organization for Economic Co-operation and Development (OECD), TG 420 (adopted in December 2001) to establish the $L_{50}$ values of the complex. Thirty numbers of Sprague Dawley rats of both sexes (nulliparous \& non-pregnant; $120 \pm 5 \mathrm{gm}$ ) were identified and allocated in five groups (six animals per group, three of each sex) plus control (dispensed in $0.5 \%$ carboxy methyl cellulose prepared as a carrier in drinking water at a dosage of $10 \mathrm{ml} / \mathrm{kg}$ body weight) and study groups (2000, 800, 600, 300 and $100 \mathrm{mg} / \mathrm{kg}$ ruthenium fluvastatin complex). The rats were allowed food and supplies immediately after drug administration and placed under three days' surveillance (67).

\section{Sub-acute toxicity studies}

Sprague Dawley rats, both male and female $(120 \pm 5 \mathrm{gm})$ were arbitrarily paired to four experimental groups: complex $(25,50,100,200 \mathrm{mg} / \mathrm{kg})$ and vehicle control group. Each unit was composed of 10 rats, 5 per gender. For further hematology, serum biochemistry and histological experiments, the animals were orally administered with rutheniumfluvastatin complex and sacrificed at 28th day by ether anesthesia.

\section{Histopathological study of rat organs}

Primary organs such as liver, kidney, stomach and testis were harvested from each participant after 28 days of analysis and stored in $10 \%$ formalin solution. Tissue was drained by graded alcohol and preserved in paraffin wax at low melting point on a 5 micron glass slide. By using xylene the sections were deparaffinized and rehydrated by graded alcohol and subsequently stained with hematoxyl and eosin (H\&E) for microscopic examination.

\section{In-vivo Experiments}

\section{Experimental Protocol}

After acclimatization, the animals were grouped into six designated units such as I, II, III, IV, V, VI, VII and each unit consisted of six animals. Once all the animals were 50 days old, DMBA was given in an oil emulsion as a single tail vein injection to group II to IV at a dosage of $0.5 \mathrm{mg}$ per $100 \mathrm{~g}$ body weight. The description below denotes the experimental layout of the groups

Group I - Animals constituted the normal untreated controls and received basal diet throughout experiment.

Group II - Comprised of carcinogen (DMBA) treated animals.

Group III- Carcinogen (DMBA) induced animals accompanied by $25 \mathrm{mg} / \mathrm{kg}$ body weight treatment with the Rufluvastatin complex. 
Group IV- Carcinogen (DMBA) induced animals accompanied by $50 \mathrm{mg} / \mathrm{kg}$ body weight treatment with the Rufluvastatin complex.

Group V-Carcinogen (DMBA) induced animals accompanied by $75 \mathrm{mg} / \mathrm{kg}$ body weight treatment with the Rufluvastatin complex.

Group VI - Carcinogen (DMBA) induced animals accompanied by $50 \mathrm{mg} / \mathrm{kg}$ body weight treatment of ruthenium.

Group VII- Carcinogen (DMBA) induced animals accompanied by $50 \mathrm{mg} / \mathrm{kg}$ body weight treatment of fluvastatin.

Following 16 weeks of treatment, the animals were sacrificed in light ether anesthesia from each group preceded by midline incision from the pubis to the sub-maxillary region. Dissection of the skin was undertaken to reveal the six sections of mammary glands

\section{Histopathology of mammary tissue}

Ten animals were randomly selected from individual group, excising the thoracic and abdominal inguinal mammary tissue from rats anesthetized with ether. Part of the breast tissue was set in $10 \%$ neutral formalin buffered, carefully washed, paraffin-coated, sliced into $5 \mu \mathrm{m}$ thick segments and mounted on slides. The tissue segments were treated with hematoxylin and eosin for histopathological investigations (H\&E).

\section{Antioxidant assay of breast tissues}

Mammary tissue was crushed and homogenized (10 percent w / v) in $0.1 \mathrm{M}$ phosphate buffer $(\mathrm{pH} 7.0)$ and centrifuged for $10 \mathrm{~min}$, and thus the generated supernatant had been used for the measurement of enzymatic antioxidants (68). The catalase reaction was analyzed using the method defined by Sinha and his associates (69). The absorbance was recorded at $620 \mathrm{~nm}$; CAT action was reported as $\mu \mathrm{Mol}$ of $\mathrm{H}_{2} \mathrm{O}_{2} / \mathrm{min} / \mathrm{mg}$ protein consumed. Superoxide dismutase activity was assessed using the Awasthi technique (70). This activity was expressed as units/min/mg protein. The GPx evaluation was carried out using the process provided by Rotruck (71). The activity was calculated as $\mu \mathrm{Mol}$ of GSH consumed $/ \mathrm{min} / \mathrm{mg}$ protein.

\section{Immunohistochemical analysis of mammary tissue}

The tissues coated with formalin and set in paraffin is sliced into $5 \mu \mathrm{m}$ thickness to position on the glass slides and deparaffinized together with immersion in $\mathrm{H}_{2} \mathrm{O}_{2}$. For 1 hour, the segments were coated with goat serum, preceded by exposure to anti-mouse p53, Bcl2, Bax and MMP-9 antibodies (1:50 ratio) and maintained overnight at $4{ }^{\circ} \mathrm{C}$. The slides were immersed with PBS and subsequently cultivated for about $30 \mathrm{~min}$ with the HRP-conjugated secondary antibody streptavidin biotin. DAB was utilized to dye the segments and counter-stained with hematoxylin. The labeling index was measured as the number of positive stained cells with p53, Bcl-2, Bax and MMP-9 to the total cell count.

\section{Cell proliferating assay}

The tissues coated with formalin and set in paraffın is sliced into $5 \mu \mathrm{m}$ thickness to position on the glass slides performed deparaffinized accompanied by submersion in $\mathrm{H}_{2} \mathrm{O}_{2}$. The segments were covered with goat serum for 1 hour, followed by exposure anti-mouse Ki- 67 antibody at $4{ }^{\circ} \mathrm{C}$ overnight. At room temperature the positive test slides were processed for 30 min with streptavidin biotin horseradish peroxidase complex. Tissues were treated with $D A B$ (3,3'- diaminobenzidine) and hematoxylin (72).

\section{TUNEL assay of mammary tissues}


Tissues fixed in formalin, implanted in paraffin, and coated with poly-L-lysine were screened for 15 minutes with proteinase $\mathrm{K}\left(20 \mu \mathrm{g} / \mathrm{ml}\right.$ in PBS) and washed with water distilled twice. The tissues were then soaked with $\mathrm{H}_{2} \mathrm{O}_{2}(2 \%$ in PBS) at room temperature for $5 \mathrm{~min}$, accompanied by treatment with the terminal deoxynucleotidyl transferase (TdT) buffer (30 mM trizma base, pH 7.2, 140 mM sodium cacodylate, 1 mM cobalt chloride) accompanied by a TdT reaction solution containing $\mathrm{TdT}$ and dUTP at $37^{\circ} \mathrm{C}$ for $90 \mathrm{~min}, 2$ percent of the normal saline citrate was then added to the tissues $(10 \mathrm{~min})$ at room temperature to interrupt the reaction. After washing with PBS the tissue segments were soaked with anti-digoxigenin peroxidase for 30 minutes at RT. Tissues were stained with DAB and counter stained with hematoxylin. Slides then were cleaned, dehydrated and stored. Apoptotic cells were thus detected by a brown staining of the nuclei (72).

\section{Evaluation of labelling and apoptotic index}

The labeling index (LI) was determined by counting the proportion of Ki-67-positive nuclei per total number of cells. The apoptotic index (AI) was calculated by measuring the TUNNEL-positive cell percentage to the total cell number.

\section{Statistical Analysis}

The findings were set to mean \pm standard mean error (SEM). Statistical assessment was carried out using t-test and one-way variance analysis ( ANOVA) using graph pad prism techniques, further verified by post-hoc measurement check (Dunnet's t test), difference was found to be statistically significant by using $P<0.05$.

\section{Results}

Pharmacophore Analysis

It is of interest to design the inhibitors for the breast cancer target Synuclein gamma (SNCG) protein, using molecular docking based virtual screening followed by molecular docking. The protein structures of SNCG was retained from PDB and the resultant structures were used for molecular modeling methods to check the resolution of amino acid arranges within the complex protein structures and predicted the active site of the amino acids. The docking results shows that SNCG interacted significantly with ruthenium-fluvastatin within the active site amino acids of both polar and electrostatic charges within the target amino acids of Thr59, Asn64, Val66, Ser67, Glu68 and Val71 with substantial energy of $-23.168 \mathrm{kcal} / \mathrm{mol}$. (Table 1 and Fig. 1B, C \& D)

Table 1

Ligand with its binding energy values from docking studies

\begin{tabular}{|c|c|c|c|c|c|c|c|}
\hline Name & $\begin{array}{l}\text { Electrostatic } \\
\text { energy }\end{array}$ & $\begin{array}{l}\text { Vanderwal } \\
\text { energy }\end{array}$ & $\begin{array}{l}\text { Cdocker } \\
\text { Energy }\end{array}$ & $\begin{array}{l}\text { Cdocker_Interaction } \\
\text { energy }\end{array}$ & $\begin{array}{l}\text { Calculate } \\
\text { binding } \\
\text { energy }\end{array}$ & $\begin{array}{l}\mathrm{H}- \\
\text { bond } \\
\text { count }\end{array}$ & $\begin{array}{l}\text { Interacting } \\
\text { Amino Acids }\end{array}$ \\
\hline $\begin{array}{l}\text { Ruthenium- } \\
\text { Fluvastatin }\end{array}$ & -23.168 & 3.03 & -234.9 & 45.31 & -56.3119 & 2 & $\begin{array}{l}\text { Thr59,Asn64, } \\
\text { Val66,Ser67, } \\
\text { Glu68,Val71 }\end{array}$ \\
\hline
\end{tabular}

Instrumental analysis

The electronic spectrum or UV spectrum of fluvastatin has shown absorption bands in two region 230-240 nm and 300-310 nm due to inter-ligand interaction. The complex only showed charge transfer between ligand to metal and metal to ligand as there was no appreciable change found in the UV-visible spectrum of the complex. So, there is no $d$ $d$ transitions are expected due to the complex formation. The first range of the wavelength can be assigned to $\pi \rightarrow \pi^{*}$ 
transitions in the aromaticity of double bond. The other range of the wavelength is most probably due to the $n \rightarrow \pi^{*}$ transition of mainly pyrrole, carboxylate and hydroxyl group (Fig. 2A). The FTIR study of the fluvastatin and ruthenium-fluvastatin complex was done to determine the co-ordination sites and binding properties of fluvastatin with ruthenium, as shown in the Fig. 2B \& C and the analysis of the data was done in the Table 2. The v $(\mathrm{O}-\mathrm{H})$ frequencies appeared as broad bands at $3376.46 \mathrm{~cm}^{-1}$ in case of fluvastatin and in case of the ruthenium-fluvastatin complex the bands was found at $3412.27 \mathrm{~cm}^{-1}$ which shows the presence of water molecules. The $v(\mathrm{C}-\mathrm{N})$ stretching mode in fluvastatin appeared at $1215.98 \mathrm{~cm}^{-1}$ and was shifted to $1220.12 \mathrm{~cm}^{-1}$ after the complex formation. The $v$ (C-F) stretching appeared at $967.80 \mathrm{~cm}^{-1}$ in spectrum of fluvastatin and shifted to 970.13 after the formation of the complex. At $1105.21 \mathrm{~cm}^{-1}$, characteristic peak of $\mathrm{v}$ (C-0) was found in fluvastatin and shifted to 1098.12 after complex formation. Another characteristic peak was found at $1570.14 \mathrm{~cm}^{-1}$ for $v(C=C)$ stretching and that also shifted at $1543.68 \mathrm{~cm}^{-1}$ in case of the complex. A characteristic peak for the formation of metal oxide bond was found at $600.14 \mathrm{~cm}^{-1},(1 \mathrm{~B})$ which was absent in case of the free fluvastatin. These results indicate that the oxygen group $(=0)$ and $(-0)$ is responsible for the chelation and formation of ruthenium-fluvastatin complex. The ${ }^{1} \mathrm{H}$ NMR spectrum of the complex is depicted in Fig. 2D shows that every signal or peak is also present in the spectrum of the complex with very less appreciable changes in their position as some sort of chemical shifts have been found after the formation of the complex, in case of complex the appearance of signals of the protons of the two methyl groups slightly shifted at $\delta 1.350 \mathrm{ppm}$, two methylene group of the 6-heptanoate as a multiplet shifted at $\delta 2.235-2.504 \mathrm{ppm}$, the three protons $-\mathrm{CH}-\mathrm{N}$ and $2-\mathrm{CH}-\mathrm{OH}$ as multiplet shifted at $\delta 4.996 \mathrm{ppm}, 2-\mathrm{OH}$ at $\delta 4.754 \mathrm{ppm}$. The two protons of the double bond of the side chain give signal as doublet at $\delta 5.708,6.598 \mathrm{ppm}$ and the eight aromatic protons give signal as a multiplet at $\delta 7.004-7.445 \mathrm{ppm}$. Hence, it indicates that the chelation is occurred on the carboxylate site. Mass spectrum of the complex is depicted in Fig. 2E where the peak $\mathrm{m} / \mathrm{z}$ at 975.47 designates the formation of the complex containing 2 fluvastatin +1 ruthenium +1 chloride +1 water molecule, the peak $\mathrm{m} / \mathrm{z} 891.33$ designates the 2 fragmented fluvastatin +1 ruthenium +1 chloride +1 water molecule, peak $\mathrm{m} / \mathrm{z}$ at 410.46 shows the free fluvastatin . The various fragmentation of the complex is depicted in Fig. 2F. The surface morphology of ruthenium-fluvastatin complex has been examined by SEM which is shown in the Fig. 2G, H \& I different magnification of the sample was observed which represents crystalline nature irregular shape of the compound. The higher magnifications confirm the crystalline nature of the complex. The crystallinity as well as the physical state of the complex was further investigate by $\mathrm{X}$-ray diffraction study, figure $\mathrm{J}$ showed appearance of sharp peaks which is typical characteristic of crystalline nature of the complex, the sharp peaks were observed at different diffraction angles such as 7.09, 10.24, 19.05, 22.78, $27.27,29.12$ and $35.88 \AA$. The sharp peaks in the diffractogram of the complex suggested that the complex is in crystalline nature.

Table 2

FTIR spectrum of Fluvastatin and Ruthenium-fluvastatin Complex (band position $\mathrm{cm}-1)$

\begin{tabular}{|lllllll|}
\hline Compound & $\mathbf{v}(\mathbf{O}-\mathrm{H})$ & $\mathbf{v}(\mathrm{C}-\mathrm{N})$ & $\mathbf{v}(\mathbf{C}-\mathrm{F})$ & $\mathbf{v}(\mathrm{C}-\mathbf{O})$ & $\mathbf{v}(\mathbf{C}=\mathbf{C})$ & $\mathbf{v}(\mathrm{M}-\mathbf{O})$ \\
\hline Fluvastatin & 3376.46 & 1215.98 & 967.80 & 1105.21 & 1570.14 & \\
\hline Complex & 3412.27 & 1220.12 & 970.13 & 1098.12 & 1543.68 & 600.14 \\
\hline
\end{tabular}

In vitro antioxidant capacity of ruthenium fluvastatin complex

\section{Ruthenium fluvastatin complex was capable of scavenging DPPH, FRAP and ABTS radicals}


Figure $3 \mathrm{~A}$, indicates that the scavenging actions of fluvastatin and ruthenium-fluvastatin by ABTS methods. Absorption of the effective ABTS solution at $734 \mathrm{~nm}$ was observed to substantially decrease in the presence of different concentrations of the complex. The complex 's ABTS radical scavenging activity has been found to be better than the free fluvastatin. The presence of hydroxyl groups causes statins to have antioxidant activity. The complex's higher antioxidant activity is due to the hydroxyl groups, and their capacity to contribute hydrogen atoms improved after ruthenium chelation.

In Fig. 3B, illustration of different DPPH absorption pattern of fluvastatin and ruthenium-fluvastatin complex at $515 \mathrm{~nm}$, with increasing amount of time and concentration. With the increase in concentration and time complex showed higher DPPH absorption than the fluvastatin molecule. The complex represented better inhibitory effect compared to the free fluvastatin, the radical-sensitive Ru-O bond was introduced to ruthenium-fluvastatinn complex which synergistically enhances antioxidant activities of fluvastatin. In Fig. 2.2, the plot illustrated the radical scavenging activity of fluvastatin and the complex, where it has been found that fluvastatin scavenged free radicals to about $47.10 \%$ and the complex scavenged about $63.17 \%$ at the same given reaction time.

The absorption of fluvastatin and ruthenium-fluvastatin complex in the presence of Fe + 3-TPTZ was estimated at $593 \mathrm{~nm}$ by absorbance variability during $10 \mathrm{~min}$ of FRAP reagent interaction with the subjected compound. The absorbance reduction is equivalent to the antioxidant quality. Figure $3 \mathrm{C}$ shows that the antioxidant capacity of the complex is improved compared with free fluvastatin. These findings indicate that the complex of fluvastatin and ruthenium is capable of making a donation of protons and thus could have the ability to end a chain reaction. Metal chelation further increases the transfer of electrons from fluvastatin and thus rises the redox potential of the ruthenium-fluvastatin complex.

Ruthenium- fluvastatin complex is capable of binding with CT-DNA

The broad absorption range in the presence of CT-DNA ( 5 microns) as can be seen in (Fig. 3 D). A decline in absorption rate (hypochromism) of the absorption peak is observed following the addition of the concentrations of the complex to CT-DNA. The intensity changes can be recognized within the intra-ligand transition band at $383 \mathrm{~nm}$, after raising the complex concentration in the DNA. These absorption spectra disclose that the complex interacts with DNA by stacking action between the ligand's chromophore via intercalative mode and the DNA base pairs.

In vitro Assessment

\section{Ruthenium fluvastatin complex instigates the repression of cell viability}

MTT assay was performed to investigate the inhibitory effect of ruthenium- fluvastatin complex on MCF-7 and MDAMB-231 cells. The cell viability evaluation revealed that ruthenium - fluvastatin complex showed a dose-dependent inhibitory impact on human breast cancer cells MCF-7 and MDA-MB-231 (Fig. 4 A \& B). Treatment with the complex was observed to decrease the viability of the MCF-7 cells to $85 \%, 69 \%, 58 \%, 49 \%$ and $31 \%$ respectively at doses of 15 , $35,55,75$ and $95 \mu \mathrm{M}$. Likewise, findings were observed in MDA-MB-231 cells where cell viability decreased to $93 \%$, $87 \%, 80 \%, 73 \%$ and $62 \%$ at concentrations $15,35,55,75$ and $95 \mu \mathrm{M}$ after 24 hours. Exposure to the complex at $95 \mu \mathrm{M}$ in MCF7 cells was observed to have a maximum inhibition rate of $69 \%$, while stimulation with $95 \mu \mathrm{M}$ of the complex on MDA-MB-231 cells displayed a maximum inhibition rate of $38 \%$ at 24 hours.

\section{Ruthenium- fluvastatin complex causes chromatin condensation}


Detection of nuclear blebbing and condensation of the chromatin were performed by using DAPI staining. Cells containing condensed chromatin morphologically signify that the cells undergoing apoptosis and fluoresce with bright blue color. Complex causes dose-dependent nuclear condensation at both cell lines (Fig. 4 C \& D). It has been observed that intervention with $100 \mu \mathrm{M}$ of complex in MCF-7 cells and $200 \mu \mathrm{M}$ of complex in MDA-MB-231 cells exhibited maximum chromatin condensation after 24 hours and represents the highest apoptosis expanse.

\section{Ruthenium fluvastatin complex encourages colony inhibition capability}

The relevance of the tumor- colony forming assessment for screening new drugs has often been identified as an important tool for research. Ruthenium-fluvastatin complex effectively stimulates the capacity of MCF-7 and MDA-MB231 cells to inhibit colony formation (Fig. 4E). In MCF-7 and MDA-MB-231 cells, ruthenium fluvastatin complex was substantially more successful in suppressing the colony number (Fig. 4 F \& I) and size (Fig. 4 G \& J) relative to control cells. Plate efficiency (PE) was measured for ruthenium fluvastatin complex for both MCF-7 and MDA-MB-231 cells (Fig. $4 \mathrm{H} \mathrm{\&} \mathrm{K}$ ) and findings indicate that PE was substantially decreased in MCF-7 and MDA-MB-231 at the maximum doses of ruthenium- fluvastatin complex.

\section{Ruthenium- fluvastatin complex initiates apoptosis arrests cell cycle}

MCF-7 and MDA-MB-231 undergoing apoptosis were observed by staining them with Annexin-V and PI by treating them with three different concentrations respectively of the complex for 24 hours. Flow cytometric study can differentiate stained cells into four categories, namely viable (Annexin-V-PI-), early apoptosis (Annexin-V + PI-), late apoptosis (Annexin-V + PI+) and necrotic (Annexin-V-PI+) cells. (Fig. 5A \& D) showed the division of cells receiving therapy with specific complex concentrations after 24 hours. The percentages of apoptotic cells are $18,37.82$ and $45.7 \%$ after exposure to 30,70 , and $100 \mu \mathrm{M}$ of the complex in MCF-7 cells and 18.2, 40.73 and $47.73 \%$ following treatment with 50, 75 and $200 \mu \mathrm{M}$ of the complex in MDA-MB-231 cells as compared to control (Fig. 5B \& E). In addition, a dose-dependent increase was also identified in the early apoptotic cells after 24 hours of complex therapy (Fig. 5 C \& F).

Flow cytometric assessment was used to analyze the proliferation processes of the cell cycle along with the content of the cellular DNA. The proportion of subdiploid cells within the cell cycle histogram is the indication of the apoptotic cells ( Fig. 5G, H). MCF-7 cells exposed to $30 \mu \mathrm{M}, 70 \mu \mathrm{M}$, and $100 \mu \mathrm{M}$ complex concentrations indicated $64.82 \%$, $60.03 \%$, and $53.45 \%$ cells in the G0 / G1 stage. Comparable findings were reported in MDA-MB-231 cells, where exposure to $50 \mu \mathrm{M}, 75 \mu \mathrm{M}$ and $200 \mu \mathrm{M}$ of the complex yielded $64.28 \%, 53.67 \%$ and $40.18 \%$ of cells in the G0 / G1 stage. At the same time an rise in cells in the S-phase was observed for both cell types in a dose-dependent fashion after complex therapy (Fig. 5 I \& J). It should also be reported that the complex causes a dose-dependent decline in the number cells in G0 / G1 stage for both cell lines.

\section{Ruthenium- fluvastatin initiates Caspase 3 mediated apoptosis}

Quantification of caspase 3 was performed in triplicate in MCF and MDA-MB-231cells, by using flow cytometry. The value has been determined based on the percentage of the cell population in respect to the caspase 3 enzyme activity during the apoptotic process. The flow cytometric evaluation of the effect of caspase 3 ruthenium fluvastatin complex treatment on both cell types after 24 hours of is shown in Fig. $5 \mathrm{~K} \& \mathrm{~L}$. The quadrant M1 represented the number of live cells without caspase 3 , while quadrant M2 corresponds to the number of active caspase 3 designated apoptotic cells. After drug therapy, the percentage of caspase 3 demarcated apoptotic cells in quadrant M2 is substantially better than that of viable cells in quadrant M1, while unexposed cells display a lower percentage of viable cells in quadrant M1 
relative to the caspase 3 demarcated apoptotic cells in quadrant M2.This observation is in accordance with the result of the apoptotic analysis, as an increment of the caspase 3 corresponds with the increase in the late apoptotic cells.

Ruthenium - fluvastatin complex modulates expression of PI3K, Akt, mTOR, EGFR, VEGF, and cleaved caspase 3.

Western blot experimentation was performed to establish the inhibition of MCF-7 and MDA-MB-231cell growth by the complex through diverse cell cycle modulatory factors variation. We verified the effects of ruthenium- fluvastatin complex treatment on various proteins like PI3K, Akt, mTOR, EGFR, VEGF, and cleaved caspase 3 in MCF 7 and MDAMB-231 cells human breast cancer cells. After 24 hours of exposure to ruthenium - fluvastatin complex in both MCF 7 and MDA-MB-231 cells, a dose-dependent down-regulation of PI3 K, Akt, mTOR, EGFR and VEGF was identified (Fig. $5 \mathrm{M}$ ). Nonetheless, a significant upregulation of cleaved caspase 3 was observed in both MCF 7 and MDA-MB-231 cells after 24 hours of exposure to ruthenium - fluvastatin therapy.

Toxicity study

\section{Acute and sub-acute toxicity study}

The LD50 dosage of ruthenium- fluvastatin complex was estimated to be $300 \mathrm{mg} / \mathrm{kg} .25,50,100$ and $300 \mathrm{mg} / \mathrm{kg}$ were chosen as the sub-acute toxic doses following the LD50 dose evaluation. No treatment-related deaths in animals treated with 25,50, 100 or 300 mg / kg of the complex were recorded during sub-acute toxicity evaluation (28 days).

\section{Analysis of hematological and serum biochemical parameters}

Tables 3, 4, 5 and 6 demonstrate the serum biochemical and hematology analysis of the treated and control animals. WBC, RBC quantities in the ruthenium- fluvastatin complex $(300 \mathrm{mg} / \mathrm{kg})$ dose groups were substantially improved in comparison to control animals. ALP,ALT and AST were slightly higher than the control group at $300 \mathrm{mg} / \mathrm{kg} \mathrm{dose}(\mathrm{p}<$ $0.05)$. Glucose and BUN were both changed slightly $(p<0.05)$ in animals administered with $300 \mathrm{mg} / \mathrm{kg}$ drug. the complex's $300 \mathrm{mg} / \mathrm{kg}$ dosage induced toxicity in animal models to some extent and was thus not considered a standard for subsequent research. 
Table 3

Hematological finding in male Swiss albino mice treated with Ruthenium-fluvastatin complex for 28 days repeateddose oral sub-acute toxicity study.

\begin{tabular}{|c|c|c|c|c|c|}
\hline $\begin{array}{l}\text { Parameters ( } \pm \\
\text { SEM) }\end{array}$ & Control & $\begin{array}{l}\text { Ru-Fluv complex } \\
(200 \mathrm{mg})\end{array}$ & $\begin{array}{l}\text { Ru-Fluv complex } \\
(100 \mathrm{mg})\end{array}$ & $\begin{array}{l}\text { Ru-Fluv complex } \\
\text { (50 mg) }\end{array}$ & $\begin{array}{l}\text { Ru-Fluv complex } \\
(25 \mathrm{mg})\end{array}$ \\
\hline $\begin{array}{l}\text { Hemoglobin } \\
\text { (\%) }\end{array}$ & $\begin{array}{l}12.30 \pm \\
0.015\end{array}$ & $13.44 \pm 0.01$ & $12.64 \pm 0.01$ & $12.25 \pm 0.01$ & $12.60 \pm 0.02$ \\
\hline $\begin{array}{l}\text { Total RBC } \\
\left(10^{6} / \mu\right)\end{array}$ & $\begin{array}{l}4.27 \pm \\
0.003\end{array}$ & $5.10 \pm 0.001^{\#}$ & $4.51 \pm 0.001$ & $4.33 \pm 0.002$ & $4.62 \pm 0.001$ \\
\hline $\begin{array}{l}\text { Platelet count } \\
\left(10^{5} / \mu\right)\end{array}$ & $\begin{array}{l}2.85 \pm \\
0.001\end{array}$ & $3.25 \pm 0.03$ & $2.55 \pm 0.004$ & $2.58 \pm 0.001$ & $2.78 \pm 0.001$ \\
\hline WBC $\left(10^{3} / \mu\right)$ & $\begin{array}{l}8.74 \pm \\
0.02\end{array}$ & $13.21 \pm 0.02^{\#}$ & $11.73 \pm 0.02$ & $3.46 \pm 0.01$ & $6.4 \pm 0.04$ \\
\hline $\operatorname{MCV}(\mathrm{fL})$ & $\begin{array}{l}88.86 \pm \\
0.01\end{array}$ & $91.34 \pm 0.01$ & $88.50 \pm 0.03$ & $89.85 \pm 0.01$ & $88.84 \pm 0.01$ \\
\hline $\mathrm{MCH}(\mathrm{pg})$ & $\begin{array}{l}28.44 \pm \\
0.01\end{array}$ & $28.97 \pm 0.09$ & $28.14 \pm 0.01$ & $28.17 \pm 0.03$ & $28.13 \pm 0.01$ \\
\hline MCHC (\%) & $\begin{array}{l}31.19 \pm \\
0.02\end{array}$ & $31.75 \pm 0.06$ & $32.84 \pm 0.01$ & $32.26 \pm 0.01$ & $32.56 \pm 0.02$ \\
\hline Neutrophil (\%) & $\begin{array}{l}28.59 \pm \\
0.10\end{array}$ & $29.14 \pm 0.02$ & $25.24 \pm 0.12$ & $27.50 \pm 0.15$ & $27.18 \pm 0.03$ \\
\hline Eosinophil (\%) & $\begin{array}{l}2.08 \pm \\
0.03\end{array}$ & $6.08 \pm 0.03$ & $6.08 \pm 0.03$ & $5.20 \pm 0.08$ & $1.04 \pm 0.01$ \\
\hline Monocytes (\%) & $\begin{array}{l}1.20 \pm \\
0.08\end{array}$ & $2.10 \pm 0.06$ & $1.20 \pm 0.08$ & $1.20 \pm 0.08$ & $2.10 \pm 0.06$ \\
\hline Basophil (\%) & $0.0 \pm 0.0$ & $0.0 \pm 0.0$ & $0.0 \pm 0.0$ & $0.0 \pm 0.0$ & $0.0 \pm 0.0$ \\
\hline \multicolumn{6}{|c|}{$\begin{array}{l}\text { Standard error of mean standard deviation }(\mathrm{SD}) / \sqrt{ } \text { Total subject. Result are analyzed by } t \text {-test and one-way ANOVA } \\
\text { and confirmed by Dunnett's multiple comparison test. MCV: mean corpuscular volume; MCH: mean corpuscular } \\
\text { hemoglobin; MCHC: mean corpuscular hemoglobin concentration; RBC: red blood cell; WBC: white blood cell. }\end{array}$} \\
\hline
\end{tabular}


Table 4

Hematological finding in female Swiss albino mice treated with Ruthenium-fluvastatin complex for 28 days repeateddose oral sub-acute toxicity study.

\begin{tabular}{|c|c|c|c|c|c|}
\hline $\begin{array}{l}\text { Parameters } \\
\text { ( } \pm \text { SEM) }\end{array}$ & Control & $\begin{array}{l}\text { Ru-Fluv complex } \\
\text { (200 mg) }\end{array}$ & $\begin{array}{l}\text { Ru-Fluv complex } \\
\text { (100 mg) }\end{array}$ & $\begin{array}{l}\text { Ru-Fluv complex } \\
\text { (50 mg) }\end{array}$ & $\begin{array}{l}\text { Ru-Fluv complex } \\
(25 \mathrm{mg})\end{array}$ \\
\hline $\begin{array}{l}\text { Hemoglobin } \\
(\%)\end{array}$ & $\begin{array}{l}12.36 \pm \\
0.024\end{array}$ & $13.36 \pm 0.13$ & $12.58 \pm 0.02$ & $12.14 \pm 0.024$ & $13.02 \pm 0.17$ \\
\hline $\begin{array}{l}\text { Total RBC } \\
\left(10^{6} / \mu\right)\end{array}$ & $\begin{array}{l}4.38 \pm \\
0.005\end{array}$ & $5.16 \pm 0.24^{\#}$ & $4.61 \pm 0.004$ & $4.42 \pm 0.003$ & $4.71 \pm 0.003$ \\
\hline $\begin{array}{l}\text { Platelet count } \\
\left(10^{5} / \mu\right)\end{array}$ & $\begin{array}{l}2.85 \pm \\
0.002\end{array}$ & $3.11 \pm 0.005$ & $2.53 \pm 0.002$ & $2.58 \pm 0.002$ & $2.78 \pm 0.002$ \\
\hline WBC $\left(10^{3} / \mu\right)$ & $\begin{array}{l}8.84 \pm \\
0.03\end{array}$ & $13.36 \pm 0.02^{\#}$ & $11.88 \pm 0.02$ & $3.72 \pm 0.03$ & $5.14 \pm 0.004$ \\
\hline MCV (fL) & $\begin{array}{l}88.96 \pm \\
0.02\end{array}$ & $91.34 \pm 0.02$ & $88.54 \pm 0.05$ & $89.06 \pm 0.23$ & $89.12 \pm 0.23$ \\
\hline $\mathrm{MCH}(\mathrm{pg})$ & $\begin{array}{l}28.16 \pm \\
0.19\end{array}$ & $29.98 \pm 0.03$ & $28.04 \pm 0.03$ & $28.06 \pm 0.02$ & $27.64 \pm 0.26$ \\
\hline MCHC (\%) & $\begin{array}{l}32.35 \pm \\
0.044\end{array}$ & $32.79 \pm 0.05$ & $31.83 \pm 0.05$ & $31.41 \pm 0.02$ & $31.77 \pm 0.03$ \\
\hline Neutrophil (\%) & $\begin{array}{l}28.72 \pm \\
0.24\end{array}$ & $32.36 \pm 0.05$ & $24.92 \pm 0.20$ & $26.92 \pm 0.20$ & $24.12 \pm 0.31$ \\
\hline Eosinophil (\%) & $\begin{array}{l}2.21 \pm \\
0.09\end{array}$ & $2.27 \pm 0.12$ & $2.08 \pm 0.04$ & $3.08 \pm 0.04$ & $2.02 \pm 0.02$ \\
\hline Monocytes (\%) & $\begin{array}{l}2.02 \pm \\
0.02\end{array}$ & $2.32 \pm 0.09$ & $1.15 \pm 0.04$ & $1.25 \pm 0.06$ & $2.15 \pm 0.01$ \\
\hline Basophil (\%) & $0.0 \pm 0.0$ & $0.0 \pm 0.0$ & $0.0 \pm 0.0$ & $0.0 \pm 0.0$ & $0.0 \pm 0.0$ \\
\hline \multicolumn{6}{|c|}{$\begin{array}{l}\text { Standard error of mean standard deviation (SD)/ } \sqrt{ } \text { Total subject. Result are analyzed by } t \text {-test and one-way ANOVA } \\
\text { and confirmed by Dunnett's multiple comparison test. MCV: mean corpuscular volume; MCH: mean corpuscular } \\
\text { hemoglobin; MCHC: mean corpuscular hemoglobin concentration; RBC: red blood cell; WBC: white blood cell. }\end{array}$} \\
\hline
\end{tabular}


Table 5

Serum biochemistry findings in male Swiss albino mice treated with Ruthenium fluvastatin complex treatment for 28 days repeat dose oral sub-acute toxicity test.

\begin{tabular}{|c|c|c|c|c|c|}
\hline Parameters ( \pm SEM) & Control & $\begin{array}{l}\text { Ru-Fluv complex } \\
(200 \mathrm{mg})\end{array}$ & $\begin{array}{l}\text { Ru-Fluv complex } \\
\text { (100 mg) }\end{array}$ & $\begin{array}{l}\text { Ru-Fluv complex } \\
\text { (50 mg) }\end{array}$ & $\begin{array}{l}\text { Ru-Fluv } \\
\text { Complex } \\
(25 \mathrm{mg})\end{array}$ \\
\hline AST & $\begin{array}{l}31.28 \pm \\
0.12\end{array}$ & $50.01 \pm 0.02^{\#}$ & $40.05 \pm 0.01$ & $35.39 \pm 0.07$ & $\begin{array}{l}32.15 \pm \\
0.04\end{array}$ \\
\hline ALT & $\begin{array}{l}31.28 \pm \\
0.08\end{array}$ & $50.06 \pm 0.02^{\#}$ & $37.54 \pm 0.04$ & $45.48 \pm 0.07$ & $\begin{array}{l}34.08 \pm \\
0.04\end{array}$ \\
\hline \multirow{2}{*}{$\begin{array}{l}\text { ALP } \\
\text { Total protein }(\mathrm{g} / \mathrm{dl})\end{array}$} & $\begin{array}{l}76.65 \pm \\
15.25\end{array}$ & $103.7 \pm 53.1^{\#}$ & & $77.3 \pm 11.80$ & \multirow{2}{*}{$\begin{array}{l}76.5 \pm \\
15.21 \\
6.22 \pm 0.14\end{array}$} \\
\hline & $\begin{array}{l}6.22 \pm \\
0.22\end{array}$ & $2.23 \pm 0.26^{\#}$ & $6.66 \pm 0.15$ & $6.14 \pm 0.10$ & \\
\hline $\begin{array}{l}\text { Blood urea nitrogen } \\
(\mathrm{mg} / \mathrm{dl})\end{array}$ & $\begin{array}{l}18.10 \pm \\
0.03\end{array}$ & $30.16 \pm 0.02^{\#}$ & $28.56 \pm 0.02$ & $28.44 \pm 0.04$ & $\begin{array}{l}19.06 \pm \\
0.02\end{array}$ \\
\hline Creatinine $(\mathrm{mg} / \mathrm{dl})$ & $\begin{array}{l}0.60 \pm \\
0.002\end{array}$ & $0.60 \pm 0.002$ & $0.60 \pm 0.002$ & $0.55 \pm 0.002$ & $\begin{array}{l}0.50 \pm \\
0.004\end{array}$ \\
\hline Glucose (mg/dl) & $\begin{array}{l}115.2 \pm \\
0.37\end{array}$ & $129.4 \pm 0.40^{\#}$ & $115.2 \pm 0.37$ & $115.7 \pm 0.23$ & $\begin{array}{l}119.4 \pm \\
0.40\end{array}$ \\
\hline Cholesterol(mg/dl) & $\begin{array}{l}47.10 \pm \\
0.044\end{array}$ & $50.12 \pm 0.05$ & $47.08 \pm 0.03$ & $45.09 \pm 0.04$ & $\begin{array}{l}43.06 \pm \\
0.04\end{array}$ \\
\hline
\end{tabular}


Table 6

Serum biochemistry in female Swiss albino mice treated with ruthenium-fluvastatin complex for 28 days repeateddose oral sub-acute toxicity study.

\begin{tabular}{|c|c|c|c|c|c|}
\hline $\begin{array}{l}\text { Parameters ( } \pm \\
\text { SEM) }\end{array}$ & Control & $\begin{array}{l}\text { Ru-Fluv complex } \\
(200 \mathrm{mg})\end{array}$ & $\begin{array}{l}\text { Ru-Fluv complex } \\
(100 \mathrm{mg})\end{array}$ & $\begin{array}{l}\text { Ru-Fluv complex } \\
(50 \mathrm{mg})\end{array}$ & $\begin{array}{l}\text { Ru-Fluv } \\
\text { Complex } \\
\text { (25 mg) }\end{array}$ \\
\hline AST & $\begin{array}{l}31.18 \pm \\
0.12\end{array}$ & $50.11 \pm 0.02^{\#}$ & $40.15 \pm 0.01$ & $35.49 \pm 0.07$ & $\begin{array}{l}32.05 \pm \\
0.04\end{array}$ \\
\hline ALT & $\begin{array}{l}31.38 \pm \\
0.08\end{array}$ & $50.16 \pm 0.02^{\#}$ & $37.64 \pm 0.04$ & $45.38 \pm 0.07$ & $\begin{array}{l}34.12 \pm \\
0.04\end{array}$ \\
\hline \multirow{2}{*}{$\begin{array}{l}\text { ALP } \\
\text { Total protein }(g / d l)\end{array}$} & $\begin{array}{l}76.42 \pm \\
10.2\end{array}$ & \multirow{2}{*}{$\begin{array}{l}109.7 \pm 12.36^{\#} \\
2.31 \pm 0.27\end{array}$} & \multirow{2}{*}{$\begin{array}{l}74.8 \pm 13.27 \\
6.12 \pm 0.15\end{array}$} & \multirow{2}{*}{$\begin{array}{l}73.3 \pm 12.80 \\
6.24 \pm 0.10\end{array}$} & $\begin{array}{l}71.5 \pm \\
15.21\end{array}$ \\
\hline & $\begin{array}{l}6.23 \pm \\
0.12\end{array}$ & & & & $\begin{array}{l}6.21 \pm \\
0.15\end{array}$ \\
\hline $\begin{array}{l}\text { Blood urea nitrogen } \\
\text { (mg/dl) }\end{array}$ & $\begin{array}{l}18.25 \pm \\
0.03\end{array}$ & $32.16 \pm 0.02^{\#}$ & $28.12 \pm 0.02$ & $28.75 \pm 0.04$ & $\begin{array}{l}19.43 \pm \\
0.02\end{array}$ \\
\hline Creatinine $(\mathrm{mg} / \mathrm{dl})$ & $\begin{array}{l}0.60 \pm \\
0.002\end{array}$ & $0.61 \pm 0.002$ & $0.62 \pm 0.002$ & $0.55 \pm 0.002$ & $\begin{array}{l}0.50 \pm \\
0.004\end{array}$ \\
\hline Glucose (mg/dl) & $\begin{array}{l}112.2 \pm \\
0.37\end{array}$ & $131.4 \pm 0.40^{\#}$ & $115.1 \pm 0.37$ & $117.7 \pm 0.23$ & $\begin{array}{l}119.4 \pm \\
0.40\end{array}$ \\
\hline Cholesterol (mg/dl) & $\begin{array}{l}47.20 \pm \\
0.04\end{array}$ & $50.02 \pm 0.05$ & $47.18 \pm 0.03$ & $45.19 \pm 0.04$ & $\begin{array}{l}43.16 \pm \\
0.04\end{array}$ \\
\hline
\end{tabular}

Standard error of mean standard deviation (SD)/ $\sqrt{ }$ Total subject. Result are analysed by t-test and one-way ANOVA and confirmed by Dunnett's multiple comparison test.

\# Significant difference at $p<0.05$, when compared with control group.

\section{Histopathology}

Histopathology of kidney (Fig. 6 [i] A) of the control group exhibited the normal structural architectural organization. The foremost morphological variations were observed at the dose of $300 \mathrm{mg} / \mathrm{kg}$ (Fig. 6 [i] E). 25 and $50 \mathrm{mg} / \mathrm{kg}$ doses did not suggest any significant animal anomalies (Fig. 6 [i] B, C), while mild bowman capsule thickening was found in animals administered with $100 \mathrm{mg} / \mathrm{kg}$ complex doses (Fig. 6 [i] D). Capsular membrane thickening (tm), cytoplasmic debris (cd), pyknotic nucleus (pn), vacuolisation (v), and node sclerosis (n) were detected at $300 \mathrm{mg} / \mathrm{kg}$ doses of the complex. Liver histopathology (Fig. 6 [ii] A), denoted normal hepatic structures in the control population while maximal doses (300 mg / kg) of ruthenium- fluvastatin complex delineated focal inflammation (fi), hepatocyte degeneration (d) and mononuclear periportal infiltration (pmi) (Fig. 6 [ii] E). Animals given dose 25, 50 and $100 \mathrm{mg} / \mathrm{kg}$ showed no critical deformity (Fig. 6[ii] B, C, D). (Fig. 6 [iii] A) shows the microscopic examination of stomach, where a dosage of $300 \mathrm{mg} / \mathrm{kg}$ of ruthenium-fluvastatin complex revealed congestion (c), hemorrhages (h) and hyperplasia of the glandular gastric zone (hyp) (Fig. 6 [iii] E). Yet histopathological differences were not found at the lower dose range (25 mg / kg, $50 \mathrm{mg} / \mathrm{kg}$, and $100 \mathrm{mg} / \mathrm{kg}$ ) (Fig. 6 [iii] B, C, D). (Fig. 6 [iv] A) shows microscopic evaluation of tests where $300 \mathrm{mg} / \mathrm{kg}$ (Fig. 6 [iv] E) of ruthenium-fluvastatin complex administered animal population displayed degeneration in seminiferous tubules (D) and edema in interstitial tissues (E) and at $100 \mathrm{mg} / \mathrm{kg}$ dose level (Fig. 6 [iv] D) degeneration (D) and hyperplasia (hyp) were detected, but no histopathological changes were found at the lower dosage points (25 mg / kg and $50 \mathrm{mg} / \mathrm{kg}$ ) (Fig. 6 [iv] B,C). 


\section{Histopathology of mammary tissue}

The normal control (group I) illustrates normal alveolar septa (as), alveoli (a), acinus (ac), serous gland (sg) and terminal duct lobular units (td), of mammary tissue kept intact as seen in Fig. 7 A. DMBA-treated section of (group II) animals revealed atrophy of the periductal, stromal and fatty tissue glands (psf), atrophy of the underlying fatty tissue (ag), atrophy of the serous glands (asg) surrounding stromal fibrosis, hyperplasia of the serous and mucous glands (ah) in their mammary tissues (Fig. 7 B). Slight hyperplasia of serous and mucinous glands (Fig. 7 C, D) was seen in the histological analysis of 25 and $50 \mathrm{mg} / \mathrm{kg}$ ruthenium - fluvastatin complex treated groups (Fig. 7C, D), while in the lowest dose category $(75 \mathrm{mg} / \mathrm{kg}$ ) there has been no evidence of hyperplasia or cell proliferation in mammary tissue and normal morphology of the cells covering the ducts was observed (Fig. 7 E). 50 mg / kg Fluvastatin-treated model revealed typical histological composition of rat mammary tissue (Fig. 7G), while 50 mg / kg ruthenium-treated animals showed gland atrophy with surrounding fatty tissue (ag) and serous gland atrophy (asg) (Fig. 7 F).

\section{Antioxidant evaluation of mammary tissues}

The fragmented mammary tissue of the carcinogen control animals has been observed with reduced levels of SOD, CAT and reduced glutathione. The animals treated with $75 \mathrm{mg} / \mathrm{kg}$ ruthenim-fluvastatin complex reported a marked rise in SOD, CAT and glutathione quantities in the homogenized mammary tissues as compared to carcinogenic control and other groups (Fig. $7 \mathrm{H}$ ).

\section{Immunohistochemical evaluation of mammary tissues}

To outline the influence of ruthenium-fluvastatin therapy on mammary cancer in rats, immunohistochemical staining approaches have been used to determine the existence of cellular biomarkers such as Bax, Bcl-2, p53 and MMP-9

(Fig. 8) (Table 7). It was found that DMBA treatment greatly raised levels of Bcl-2 (Fig. 8 [ii] B) and MMP-9 (Fig. 8 [iv] B), whilst also downregulating levels of Bax (Fig. 8 [iii] B), p53 (Fig. 8I B) as compared to the control group control group ( Fig. 8 I iii, iv] A) (p<0.05). The expression of Bax (Fig. 8 [iii] C, D, E) and p53 (Fig. 8 I C, D, E) was greatly improved by ruthenium-fluvastatin therapy, but Bcl-2 (Fig. 8 [ii] C, D, E) and MMP-9 (Fig. 8 [iv] C, D, E) were significantly decreased after ruthenium-fluvastatin therapy. The dosage of $75 \mathrm{mg} / \mathrm{kg}$ ruthenium-fluvastatin complex was effective in raising the concentrations of Bax and p53 while the concentrations of Bcl-2 and MMP-9 $(p<0.01)$ showed a substantial decrease relative to those of carcinogen treated animals. The presence of the above-mentioned biomarkers allows one to believe that the complex focuses on apoptosis and thus regulates the cell cycle to effectively constrain the progression of disease. 
Table 7

Effect of ruthenium, fluvastatin and ruthenium fluvastatin complex on the expression of $\mathrm{Bax}, \mathrm{Bcl} 2, \mathrm{p} 53$ and MMP9 in breast tissues.

\begin{tabular}{|c|c|c|c|c|}
\hline Groups & p53§ & $\mathrm{Bcl} 2^{\S}$ & Bax§ & MMP9§ \\
\hline Control & $8.5 \pm 0.2$ & $7.1 \pm 0.7$ & $7.9 \pm 0.3$ & $8.3 \pm 0.1$ \\
\hline DMBA & $3.2 \pm 0.8$ & $15.2 \pm 1.8$ & $3.5 \pm 0.7$ & $19.5 \pm 0.7$ \\
\hline Ru-flu 25 mg/kg & $6.7 \pm 0.1$ & $12.6 \pm 0.3^{* *}$ & $4.1 \pm 0.8^{\star \star}$ & $15.5 \pm 0.2$ \\
\hline Ru- flu 50 mg/kg & $8.7 \pm 0.2^{\star \star}$ & $9.6 \pm 0.4^{\star \star}$ & $5.2 \pm 0.7 *$ & $12.7 \pm 0.8^{\star \star}$ \\
\hline Ru- flu 75 mg/kg & $9.3 \pm 0.9^{*}$ & $7.2 \pm 0.9^{*}$ & $8.3 \pm 1.6^{*}$ & $10.2 \pm 0.1^{*}$ \\
\hline Ru 50 mg/kg & $6.4 \pm 0.4$ & $10.2 \pm 0.5$ & $4.5 \pm 0.7$ & $14.7 \pm 0.2$ \\
\hline Flu 50 mg/kg & $5.5 \pm 0.9$ & $11.7 \pm 1.2$ & $4.9 \pm 0.3$ & $16.4 \pm 1.6$ \\
\hline \multicolumn{5}{|c|}{$\begin{array}{l}\text { SEach score represents the results of } 6 \text { slides per rat and } 6 \text { rats per group, mean } \pm \text { S.E. }(n=6) \text {. Each field were } \\
\text { selected randomly for evaluation of percentage of immune-positive cells. }\end{array}$} \\
\hline \multicolumn{5}{|c|}{ * Significant difference between treated and carcinogen control $(p<0.01)$. } \\
\hline
\end{tabular}

\section{Suppression of Ki-67 by Ruthenium-fluvastatin complex in the mammary tissue}

The potency of the ruthenium-fluvastatin molecule in mammary tissue proliferation has been depicted in Fig. 9[i]. The $\mathrm{LI}$ (labeling index) is measured as a proportion of Ki-67 tagged cells shown in Table 8. A substantial improvement in the Ki-67-LI activity was found in the DMBA treated animals (Fig. 9 I B) compared with the normal control group ( Fig. 9I A), but a small decrease in the Ki-67-LI value was found in the highest dose of ruthenium-fluvastatin complex treated animals $(p<0.01)$ (Fig. 9I C, D, E) relative to carcinogen control animals. 
Table 8

Cell proliferation and apoptosis in breast

\begin{tabular}{|llll|}
\hline Groups & Ki-67-LI\$ & Al $(\%)^{\S}$ & $R=$ Ki-67-LI /Al \\
\hline Normal control & $21.08 \pm 0.4$ & $0.16 \pm 0.02$ & $131.75 \pm 0.2$ \\
\hline DMBA & $38.9 \pm 1.3$ & $0.07 \pm 0.02$ & $555.714 \pm 0.5$ \\
\hline Ru-flu 25 mg/kg & $26.3 \pm 0.2$ & $0.09 \pm 0.05$ & $292.222 \pm 0.1$ \\
\hline Ru- flu 50 mg/kg & $22.8 \pm 0.1^{\star *}$ & $0.14 \pm 0.02^{\# \#}$ & $162.857 \pm 0.2^{\$ \$}$ \\
\hline Ru- flu 75 mg/kg & $19.3 \pm 0.6^{*}$ & $0.16 \pm 0.03^{\#}$ & $120.625 \pm 0.9^{\$}$ \\
\hline Ru $50 ~ \mathrm{mg} / \mathrm{kg}$ & $24.8 \pm 0.1$ & $0.07 \pm 0.02$ & $354.245 \pm 0.4$ \\
\hline Flu 50 mg/kg & $27.8 \pm 0.6$ & $0.11 \pm 0.04$ & $252.727 \pm 0.2$ \\
\hline
\end{tabular}

$\mathrm{LI}=$ Labelling index, $\mathrm{Ki}-67-\mathrm{LI}=$ percentage of PCNA labelled cells/total number of cells counted, $\mathrm{Al}=$ Apoptotic index. $\mathrm{R}=\mathrm{PCNA}-\mathrm{LI} / \mathrm{Al}$. Al was calculated as the percentage of TUNEL positive cells/total number of cells counted. Values represents mean \pm S.E.

$\S$ Total number of six slides were evaluated per rat. Each field consisted of approximately 500 cells.

* Significant difference between Ki-67-LI of Ru-flu 75 mg/kg vs carcinogen control animals $(p<0.01)$.

** Significant difference between Ki-67-LI of Ru 50 mg/kg, Ru-flu 50 mg/kg vs carcinogen control animals $(p<$ $0.05)$.

\#Significant difference between Al of Ru-flu 75 mg/kg vs carcinogen control $(p<0.01)$.

\#\# Significant difference between Al of Ru 50 mg/kg, Ru-flu 50 mg/kg vs carcinogen control animals $(p<0.05)$.

\$ Significant difference between R of Ru-flu $75 \mathrm{mg} / \mathrm{kg}$ vs carcinogen control animals $(p<0.01)$.

\$S Significant difference between R of Ru 50 mg/kg, Ru-flu 50 mg/kg vs carcinogen control animals $(p<0.05)$.

\section{Ruthenium-fluvastatin complex promotes apoptosis in mammary tissue}

TUNNEL assay was performed to evaluate the outcome of apoptosis with ruthenium-fluvastatin therapy in mammary carcinogenesis (Fig. 9[ii]). Apoptosis prompts the nuclear DNA to be fragmented into different segments that create DNA strand breaks that could be identified by the brown marks produced by DAB chromogen. Normal control cells undergoing cell death have been displayed in (Fig. 9[ii] A). In the carcinogen control group, the TUNEL labelled cells enduring apoptosis were very limited (Fig. 9[ii] B), while the TUNEL label cells of ruthenium-fluvastatin treated animals dramatically increased (Fig. 9[ii] C, D, E). Typically 3 to 5 apoptotic cells were found in an environment of approximately 700 cells throughout the carcinogen control group, which increased to 10-14 cells per 700 cells in the $75 \mathrm{mg} / \mathrm{kg}$ of the complex administered animals. Al specifies the apoptotic index and appears in Table 8. Animals obtaining $75 \mathrm{mg} / \mathrm{kg}$ of the drug, when compared with the carcinogen control group, represented a marked increase in apoptosis. $\mathrm{R}$ value represents the relationship between cell proliferation and apoptosis. Cell proliferation and TUNNEL evaluation suggest that the new improvements in the tumor's microenvironment could be followed by a parallel rise in cell proliferation and a minimization of cell death. $\mathrm{R}$ 's value hits a plateau in the carcinogen control group; however, it gradually decreases with the complex's increasing concentration. Through mentioning both of these hypotheses we 
can conclude that the complex activates apoptosis and ultimately decreases cell proliferation in a dose dependent manner.

\section{Discussion}

Current anticancer drugs obtained from metal complexes, focus entirely on inducing cell apoptosis and offer substantial improvements in pharmacological studies (73). This change was spectacularly motivated by the discovery of platinum-based antitumor drugs but various obstacles such as extreme adverse side effects, drug resistance, mutation aggregation and epimutations cause us to come up with alternative therapies. In their research paper Allardyce and Dyson explained that another platinum group metal, ruthenium, exhibits similar propitious biological properties (74) and is further able to establish strong chemical bonds through variable electronegativity thus rendering it capable to interact with a variety of biomolecules (75).

A lot of emerging chemotherapeutics utilize apoptosis as a mechanism to induce cellular death in tumor cells (76). To prevent apoptosis, a tumor may gain a variety of mutations or alterations. While, escaping from programmed cell death is a crucial feature of tumourigenesis, it does not appear to be a general response to all apoptotic stressors. Arguably, some of the apoptotic mechanisms and pathways in tumours stay unchanged, making them ideal candidates for therapeutic targeting (77). Among other molecules, statins have been found to have apoptosis-inducing properties. The potency of statins as an anticancer therapy has been explored both in monotherapy and in combined regimens with commonly used chemotherapeutics (78). Several reports have also indicated that statins caused programmed cell death in a subset of tumor-derived cell lines in vitro, indicating that the analogous cancers might be susceptible to statin-specific apoptosis in vivo $(79,80,81)$. Thus, the present study, focuses on exploring the potential effects of the ruthenium fluvastatin complex on in vitro and in vivo breast cancer models.

Synuclein- $\triangle(S N C G)$, is a member of the synuclein family, that has been implicated in both neurodegenerative diseases and cancer (82). A collection of functional experiments has shown that SNCG's ectopic expression in human breast cancer cells facilitates proliferation and migration (38). SNGC inhibitors have been investigated extensively based on previous studies and offer significant probability as a future drug target (83). Inspired by this data, and extensively exploring this problem, we decided to take benefit of molecular docking analyses to evaluate and explore the novel complex's binding mechanism against SNCG as a target protein.

Our findings showed that the unrestricted binding energy for the complex was low, thus promoting the binding direction of the compounds in the SNCG binding pocket circling the active site, resulting in enzyme inhibition. The complex has been identified as an inhibitory SNCG agent, and could be viewed as a potential ligand for breast cancer therapy. In fact, our research included the synthesis and characterization of the complex. We utilized different spectroscopic evaluations to evaluate fluvastatin's antioxidant capacity pre and post complex formation. Results confirm that oxygen group $(=0)$ and hydroxyl group is responsible for the chelation and formation of rutheniumfluvastatin complex and that it is crystalline in nature. The analysis of antioxidant activity showed that the mechanism of free radical scavenging of fluvastatin on resultant metal complexation is greatly enhanced. Ruthenium thus promotes the modification of fluvastatins 's oxidative ability after complexation by enhancing the transfer of electrons from fluvastatin and thus raising its redox potential. The complex 's reaction towards CT-DNA led to a reduction in the absorption spectra as compared to that of uncombined DNA, thus confirming that the complex bind through intercalation mode with CT-DNA.

The next research section was devoted to evaluating the impact of the ruthenium fluvastatin complex on the cancer cell lines MCF-7 and MDA-MB-231. MTT assay showed that complex ruthenium fluvastatin can minimize cell

Page 23/41 
proliferation and induce apoptosis. One of most important purposes of anticancer therapies is the modulation of the cell cycle, specifically the inhibition of phases G1 and G2 plays a key role in the cell cycle cascade (84). To determine the complex's mechanistic approach to the induction of apoptosis, flow cytometric experiments were employed that made use of Annexin-V and PI staining procedures. Furthermore, the results revealed that a higher percentage of early apoptotic events were identified on both MCF-7 and MDA-MB-231 cancer cells by ruthenium fluvastatin treatment, resulting in the arrest of the G0 / G1 point, amounting to cellular death.

In addition, a cell-oriented reporter analysis was performed to identify the effects of complex treatment on the presence of PI3 K, Akt, mTOR, EGFR and VEGF associated signaling trails. The PI3K / Akt / mTOR pathway is a cell signaling cascade associated with growth modulation, proliferation, reproduction, motility, metabolism and immune response $(85,86)$. The mammalian target of rapamycin (mTOR) strongly engages in various tumor progression processes by activating the signaling pathways PI3K / Akt (87). Alterations are found in nearly all human tumors, especially with breast cancer, of which up to $60 \%$ of tumors represent unique configurations that activate this cascade (88). Dysregulation of this mechanism covers a wide variety of cancer symptoms including unchecked proliferation, genomic disturbance and metabolic reconfiguring in tumor cells $(73,89)$. In fact, activation of the PI3 K / Akt / mTOR pathway is one of the major causes of current cancer chemotherapy resistance (90). It aims to make the PI3K / Akt / mTOR pathway a critical research target for understanding the development and progression of this disease, the importance of this pathway as a potential therapeutic approach along with the prognostic and diagnostic value of this pathway in patients with breast cancer is undeniable $(91,92)$. Thus, our studies denote that ruthenium-fluvastatin complex effectively, downregulates PI3K, Akt and mTOR in both MCF-7 and MDA-MB-231 cells.

Apart from these, the growth factor of the epidermis and its receptors (EGFR) in breast cancer are continuously often over-expressed (93). EGFR is a transmembrane tyrosine kinase receptor that regulates cell proliferation and epithelial cell viability via the PI3K / Akt / mTOR and protein kinase mitogen activated (MAPK) signaling cascade (94). The epidermal growth factor pathway serves as a primary mediator for breast cancer initiation and progression by encouraging the proliferation of cancer cells, their survival and promoting resistance to conventional therapy (95). In cancer chemotherapeutics, epidermal growth factor receptors and their ligands are thoroughly studied due to their mutation and over-expression in a large segment of primary breast carcinomas $(96,97,98)$. Likewise, the growth regulation signaling cascade involving the vascular endothelial growth factor (VEGF), binds to the VEGF receptor 2 (VEGFR2) and activates tumor vasculature (99). Therefore, the inhibition of the signaling pathways EGFR and VEGF is also a promising technique for cancer chemotherapy (100). Our western blot findings provide definitive proof that the complex operates both in MCF-7 and MDA-MB-231 cells via the EGFR and VEGF pathways by down regulation of their signals.

Apoptosis is a crucial and essential method of ideally programmed cell death that involves eliminating dysfunctional cells in mammalian development, and retaining tissue homeostasis. Apoptotic activation has been considered an essential and effective cancer treatment approach (101). In our current research, DAPI staining approach used fluorescence microscopy in MCF7 and MDA-MB231 cells to explore modification of nuclear morphology. Treatment with ruthenium fluvastatin complex has shown condensed chromatin and scattered nuclei, which specifically demonstrate apoptosis induction in these cells.

The global harmonized program for classifying and marking chemicals involves the reporting of a safe dose for a novel anti-cancer molecule (102). Therefore, an acute and subacute toxicological analysis was performed to determine the LD50 value and appropriate doses of the complex. The findings of our in vivo work further indicate that ruthenium-fluvastatin complex functions through the escalation of the proteins Caspase-3 and p53 and also downregulates the expresses PI3 K, Akt, mTOR, EGFR and VEGF. Recent research reportedly centered on the role of p53

Page 24/41 
in regulating the growth of cells induced by intense oncogenic signals or replicative stress (103). P53 Controls the function of large numbers of target genes related to cell cycle capture, DNA repair, senescence and apoptosis when activated (104). Contrary to other cells, cancer cells exhibit elevated mutation levels in the p53 gene. P53-dependent $\mathrm{p} 21^{\mathrm{cip} 1}$ upregulation induces misregulation of DNA replication and has been documented in active cancer cells (105). Upregulation of p53 in tumors has been documented to cause senescence-induced tumor progression (106). In addition, the activation of the pro-survival and anti-apoptotic proteins causes the cancer cells to proliferate and survive. This mechanism facilitates tumor development and the progression of the disease. DNA damage modulates P53 based signals from a molecular point of view, which also contributes to pro-apoptotic stimuli $(107,108)$. Proapoptotic proteins such as Bax disrupt the mitochondrial membranes and promote the release of cytochrome $c$ and other pro-apoptotic stimuli through the use of anti-apoptotic proteins such as Bcl-2 and BclxL (109). Our western blot and immunohistochemical results revealed that expression p53, caspase-3 and Bax were up-regulated, while the role of $\mathrm{Bcl}-2$ proteins was down-regulated, thus endorsing our hypothesis that the novel complex operates via the intrinsic apoptotic pathway Bax and Bcl-2 supported by $\mathrm{p} 53$.

Consequently, MMP-9, which belongs to a class of zinc-dependent endopeptidases, was down-regulated with ruthenium-fluvastatin treatment. Some of the most frequently observed MMPs is MMP-9, which plays a significant role in breast cancer tumor colonization, metastasis and epithelial-to-mesenchymal transition (110). investigators studied the signatures of MMP-9 in healthy and cancer breast tissue with various molecular subtypes (111) which showed a marked increase in the expression of MMP-9 in cancer tissues relative to ordinary ones (112). Additionally, it was discovered that MMP-9 was differentially expressed within different molecular subtypes of breast cancer (111).

New findings suggest that two common features of tumors are alteration of the redox equilibrium and abolition of redox signals that are closely correlated with malignancy and drug resistance (113). Therefore, it can be predicted that the up-regulation of SOD, GSH and CAT will contribute to a rise in $\mathrm{H}_{2} \mathrm{O}_{2}$ levels in the mitochondria, which is a major signaling molecule and a 'reactive oxygen species' (114). Several experiments have shown that mitochondrial $\mathrm{H}_{2} \mathrm{O}_{2}$ is a strong and efficient inducer of the apoptotic cycle (115). Treatment with ruthenium-fluvastatin complex substantially improved the production of SOD, CAT and GSH in breast cancer, possibly through enabling ROS to induce apoptotic events.

Uncontrolled proliferation is a signature of tumors and can be analyzed using a variety of methods, including the counting of mitotic figures in stained tissue samples, the inclusion of labeled nucleotides in DNA and the cytometric flow measurement of the percentage in the $S$ stage of a cell cycle (116). Dowsett determined that an immunohistochemical test of Ki-67 antigen was one of the most important approaches for quantifying proliferation (117). Ki-67 is predominant in all cancer cells and its role as a proliferation predictor is of great importance. The proliferation biomarker $\mathrm{Ki}-67$ has also been regarded as a diagnostic biomarker for breast cancer in many studies $(118,119)$. Our analysis shows that the carcinogen control animals displayed a rise in the number of cells labelled with $\mathrm{Ki}-67$ by decreasing $\mathrm{Al}$, suggesting cell proliferation in the breast tissue. At the other hand, after treatment with ruthenium-fluvastatin complex, a decrease in cells labeled with $\mathrm{Ki}-67$ and consequent rise in Al was observed.

In summary, the ruthenium-fluvastatin complex is accountable for p53 interfering apoptosis in breast carcinoma, facilitated by the intrinsic apoptotic path provoked by Bcl2 and Bax and simultaneously regulating the PI3K / Akt / mTOR pathway in conjunction with MMP9 regulated invasive tumor pathways. Moreover, the complex reveals antiangiogenic functions by decreasing the EGFR and VEGF biomarkers as well. At the same time, the complex showed a high activity of its free radical scavenging potential in breast carcinoma cells caused by the release of reactive oxygen species extracted from mitochondrial through p53 regulation. The drop in Ki-67 coupled with stimulation of p53 further increases apoptosis attained by limiting cell proliferation. The observations offer ample

Page 25/41 
proof that low doses of ruthenium-fluvastatin chemotherapy that could interrupt, suspend or delay breast carcinoma development by observing that the biomarkers co-related with the inhibition of apoptotic processes in breast carcinoma.

\section{Declarations}

\section{Acknowledgements}

The author's would like to thank Department of Oncology, Nanjing First Hospital Nanjing Medical University for their unending support.

\section{Authors' contributions}

WL, JS, HX and XW conceptualized and designed the study. WL and JS aided in acquiring and analyzing data, drafted and critically revised the manuscript. WL, JS and HX participated in experiments and the data analysis. XW was involved in study design, analyzing and interpreting the data, and critically revised the manuscript. All authors read and approved the final manuscript.

\section{Funding}

This work was supported by National Natural Science Foundation of China (81702619).

\section{Availability of data and materials}

The datasets used and/or analyzed during the current study are available from the corresponding author on reasonable request.

\section{Ethics approval and consent to participate}

The study protocol was designed and approved by the Animal Ethics Committee of Nanjing Medical University \& the Government's Regulatory Body (IACUS-1912129).

\section{Consent for publication}

Written informed consent for publication was obtained from all participants.

\section{Competing interests}

The authors declare that they have no competing interests.

\section{Author details}

${ }^{1}$ Department of Oncology, Nanjing First Hospital Nanjing Medical University, Nanjing, 210006, China.

\section{References}

1. Bidoli E, Virdone S, Hamdi-Cherif M, Toffolutti F, Taborelli M, Panato C, et al. Worldwide Age at Onset of Female Breast Cancer: A 25-Year Population-Based Cancer Registry Study. Sci Rep. 2019;9(1):14111.

2. Lei F, Paul EG, Kathrin SW. Current Status and Future Projections of Breast Cancer in Asia. Breast Care (Basel). 2015;10(6):372-8. 
3. Wang P, Xu C, Yu C. Age-period-cohort analysis on the cancer mortality in rural China: 1990-2010. Int J Equity Health. 2014;13:1.

4. Sung $H$, Rosenberg PS, Chen WQ, Hartman M, Lim WY, Chia KS, et al. Female breast cancer incidence among Asian and Western populations: more similar than expected. J Natl Cancer Inst. 2015;107(7):djv107.

5. Mubarik S, Malik SS, Wang Z, Li C, Fawad M, Yu C. Recent insights into breast cancer incidence trends among four Asian countries using age-period-cohort model. Cancer Manag Res. 2019;11:8145-55.

6. Stebbing J, Slater S, Slevin M. Breast cancer (metastatic). BMJ Clin Evid. 2007;2007:0811.

7. Andresen V, Gjertsen BT. Drug Repurposing for the Treatment of Acute Myeloid Leukemia. Front Med (Lausanne). 2017;4:211.

8. Foucquier J, Guedj M. Analysis of drug combinations: current methodological landscape. Pharmacol Res Perspect. 2015;3(3):e00149.

9. Hernandez JJ, Pryszlak M, Smith L, Yanchus C, Kurji N, Shahani VM, Molinski SV. Giving Drugs a Second Chance: Overcoming Regulatory and Financial Hurdles in Repurposing Approved Drugs As Cancer Therapeutics. Front Oncol. 2017;7:273.

10. Lu DY, Lu TR, Yarla NS, Wu HY, Xu B, Ding J, et al. Drug Combination in Clinical Cancer Treatments. Rev Recent Clin Trials. 2017;12(3):202-11.

11. Bayat Mokhtari R, Homayouni TS, Baluch N, Morgatskaya E, Kumar S, Das B, et al. Combination therapy in combating cancer. Oncotarget. 2017;8(23):38022-43.

12. Wang CY, Liu PY, Liao JK. Pleiotropic effects of statin therapy: molecular mechanisms and clinical results. Trends Mol Med. 2008;14(1):37-44.

13. Ahmadi Y, Ghorbanihaghjo A, Argani H. The balance between induction and inhibition of mevalonate pathway regulates cancer suppression by statins: A review of molecular mechanisms. Chem Biol Interact. 2017;273:27385.

14. Cauley JA, McTiernan A, Rodabough RJ, LaCroix A, Bauer DC, Margolis KL, et al Women's Health Initiative Research Group. Statin use and breast cancer: prospective results from the Women's Health Initiative. J Natl Cancer Inst. 2006;98(10):700-7.

15. Ahern TP, Pedersen L, Tarp M, Cronin-Fenton DP, Garne JP, Silliman RA, et al. Statin prescriptions and breast cancer recurrence risk: a Danish nationwide prospective cohort study. J Natl Cancer Inst. 2011;103(19):1461-8.

16. Demierre MF, Higgins PD, Gruber SB, Hawk E, Lippman SM. Statins and cancer prevention. Nat Rev Cancer. 2005;5(12):930-42.

17. Kumar AS, Benz CC, Shim V, Minami CA, Moore DH, Esserman LJ. Estrogen receptor-negative breast cancer is less likely to arise among lipophilic statin users. Cancer Epidemiol Biomarkers Prev. 2008;17(5):1028-33.

18. Hindler K, Cleeland CS, Rivera E, Collard CD. The role of statins in cancer therapy. Oncologist. 2006;11(3):306-15.

19. Lakha F, Theodoratou E, Farrington SM, Tenesa A, Cetnarskyj R, Din FV, et al. Statin use and association with colorectal cancer survival and risk: case control study with prescription data linkage. BMC Cancer. 2012;12:487.

20. Chiu HF, Ho SC, Chang CC, Wu TN, Yang CY. Statins are associated with a reduced risk of gastric cancer: a population-based case-control study. Am J Gastroenterol. 2011;106(12):2098-103.

21. Lang L. Statins may lower colorectal Cancer risk. Gastroenterology. 2005;129:5.

22. Vinayak S, Kurian AW. Statins May Reduce Breast Cancer Risk, Particularly Hormone Receptor-Negative Disease. Curr Breast Cancer Rep. 2009;1(3):148-56. 
23. El-Serag HB, Johnson ML, Hachem C, Morgana RO. Statins are associated with a reduced risk of hepatocellular carcinoma in a large cohort of patients with diabetes. Gastroenterology. 2009;136(5):1601-8.

24. Platz EA, Leitzmann MF, Visvanathan K, Rimm EB, Stampfer MJ, Willett WC, et al. Statin drugs and risk of advanced prostate cancer. J Natl Cancer Inst. 2006;98(24):1819-25.

25. Khurana V, Bejjanki HR, Caldito G, Owens MW. Statins reduce the risk of lung cancer in humans: a large casecontrol study of US veterans. Chest. 2007;131(5):1282-8.

26. Bradley MC, Hughes CM, Cantwell MM, Murray LJ. Statins and pancreatic cancer risk: a nested case-control study. Cancer Causes Control. 2010;21(12):2093-100.

27. Sławińska-Brych A, Zdzisińska B, Kandefer-Szerszeń M. Fluvastatin inhibits growth and alters the malignant phenotype of the C6 glioma cell line. Pharmacol Rep. 2014;66(1):121-9.

28. Kanugula AK, Dhople VM, Völker U, Ummanni R, Kotamraju S. Fluvastatin mediated breast cancer cell death: a proteomic approach to identify differentially regulated proteins in MDA-MB-231 cells. PLoS One. 2014;9(9):e108890.

29. Zhang W, Wu J, Zhou L, Xie HY, Zheng SS. Fluvastatin, a lipophilic statin, induces apoptosis in human hepatocellular carcinoma cells through mitochondria-operated pathway. Indian J Exp Biol. 2010;48(12):1167-74.

30. Gbelcová H, Lenícek M, Zelenka J, Knejzlík Z, Dvoráková G, Zadinová M, et al. Differences in antitumor effects of various statins on human pancreatic cancer. Int J Cancer. 2008;122(6):1214-21.

31. Bergamo A, Sava G. Ruthenium anticancer compounds: myths and realities of the emerging metal-based drugs. Dalton Trans. 2011;40(31):7817-23.

32. Trondl R, Heffeter P, Kowol CR, Jakupec MA, Berger W, Keppler BK. NKP-1339, the first ruthenium-based anticancer drug on the edge to clinical application. Chem Sci. 2014;5:2925-32.

33. Alessio E. Thirty Years of the Drug Candidate NAMI-A and the Myths in the Field of Ruthenium Anticancer Compounds: A Personal Perspective. Eur J Inorg Chem. 2017;12:1549-60.

34. Vock CA, Ang WH, Scolaro C, Phillips AD, Lagopoulos $L$, Juillerat-Jeanneret $L$, et al. Development of ruthenium antitumor drugs that overcome multidrug resistance mechanisms. J Med Chem. 2007;50(9):2166-75.

35. Berndsen RH, Weiss A, Abdul UK, Wong TJ, Meraldi P, Griffioen AW, et al. Combination of ruthenium(II)-arene complex [Ru(n6-p-cymene)Cl2(pta)] (RAPTA-C) and the epidermal growth factor receptor inhibitor erlotinib results in efficient angiostatic and antitumor activity. Sci Rep. 2017;7:43005.

36. Alessio E, Messori L. NAMI-A and KP1019/1339, Two Iconic Ruthenium Anticancer Drug Candidates Face-to-Face: A Case Story in Medicinal Inorganic Chemistry. Molecules. 2019;24(10):1995.

37. Zhang J, Liu XH, Li C, Wu XX, Chen YL, Li WW, et al. SNCG promotes the progression and metastasis of high-grade serous ovarian cancer via targeting the PI3K/AKT signaling pathway. J Exp Clin Cancer Res. 2020;39(1):79.

38. Jia T, Liu YE, Liu J, Shi YE. Stimulation of breast cancer invasion and metastasis by synuclein gamma. Cancer Res. 1999;59(3):742-7.

39. Gupta A, Godwin AK, Vanderveer L, Lu A, Liu J. Hypomethylation of the synuclein gamma gene CpG island promotes its aberrant expression in breast carcinoma and ovarian carcinoma. Cancer Res. 2003;63(3):664-73.

40. Wu K, Weng Z, Tao Q, Lin G, Wu X, Qian H, et al. Stage-specific expression of breast cancer-specific gene gammasynuclein. Cancer Epidemiol Biomarkers Prev. 2003;12(9):920-5.

41. Bruening W, Giasson BI, Klein-Szanto AJ, Lee VM, Trojanowski JQ, Godwin AK. Synucleins are expressed in the majority of breast and ovarian carcinomas and in preneoplastic lesions of the ovary. Cancer. 2000;88(9):215463.

Page 28/41 
42. Jiang Y, Liu YE, Goldberg ID, Shi YE. Gamma synuclein, a novel heat-shock protein-associated chaperone, stimulates ligand-dependent estrogen receptor alpha signaling and mammary tumorigenesis. Cancer Res. 2004;64(13):4539-46.

43. Jiang Y, Liu YE, Lu A, Gupta A, Goldberg ID, Liu J, et al. Stimulation of estrogen receptor signaling by gamma synuclein. Cancer Res. 2003 Jul 15;63(14):3899-903.

44. Inaba S, Li C, Shi YE, Song DQ, Jiang JD, Liu J. Synuclein gamma inhibits the mitotic checkpoint function and promotes chromosomal instability of breast cancer cells. Breast Cancer Res Treat. 2005;94(1):25-35.

45. Parmar F, Patel C, Highland H, Pandya H, George LB. Antiproliferative efficacy of kaempferol on cultured daudi cells: An in silico and in vitro study. Adv Biol. 2016; 2016: 1-10.

46. Zhang S, Kumar K, Jiang X, Wallqvist A, Reifman J. DOVIS: an implementation for high-throughput virtual screening using AutoDock. BMC Bioinformatics. 2008;9:126.

47. Parton M, Dowsett M, Smith I. Studies of apoptosis in breast cancer. BMJ. 2001;322(7301):1528-32.

48. Sankar Ray R, Roy S, Ghosh S, Kumar M, Chatterjee M. Suppression of cell proliferation, DNA protein cross-links, and induction of apoptosis by vanadium in chemical rat mammary carcinogenesis. Biochim Biophys Acta. 2004;1675(1-3):165-73.

49. Binder C, Marx D, Binder L, Schauer A, Hiddemann W. Expression of Bax in relation to Bcl-2 and other predictive parameters in breast cancer. Ann Oncol. 1996 Feb;7(2):129-33.

50. Krajewski S, Thor AD, Edgerton SM, Moore DH 2nd, Krajewska M, Reed JC. Analysis of Bax and Bcl-2 expression in p53-immunopositive breast cancers. Clin Cancer Res. 1997;3(2):199-208.

51. Xin M, Deng X. Nicotine inactivation of the proapoptotic function of Bax through phosphorylation. J Biol Chem. 2005;280(11):10781-9.

52. Bayramoglu A, Gunes HV, Metintas M, Değirmenci I, Mutlu F, Alataş F. The association of MMP-9 enzyme activity, MMP-9 C1562T polymorphism, and MMP-2 and - 9 and TIMP-1, -2, -3, and - 4 gene expression in lung cancer. Genet Test Mol Biomarkers. 2009;13(5):671-8.

53. Adams J, Carder PJ, Downey S, Forbes MA, MacLennan K, Allgar V, et al. Vascular endothelial growth factor (VEGF) in breast cancer: comparison of plasma, serum, and tissue VEGF and microvessel density and effects of tamoxifen. Cancer Res. 2000;60(11):2898-905.

54. Ray RS, Ghosh B, Rana A, Chatterjee M. Suppression of cell proliferation, induction of apoptosis and cell cycle arrest: chemopreventive activity of vanadium in vivo and in vitro. Int J Cancer. 2007;120(1):13-23.

55. Anbuselvam C, Vijayavel K, Balasubramanian MP. Protective effect of Operculina turpethum against 7,12-dimethyl benz(a)anthracene induced oxidative stress with reference to breast cancer in experimental rats. Chem Biol Interact. 2007;168(3):229-36.

56. Davison CA, Durbin SM, Thau MR, Zellmer VR, Chapman SE, Diener J, et al. Antioxidant enzymes mediate survival of breast cancer cells deprived of extracellular matrix. Cancer Res. 2013;73(12):3704-15.

57. Padmavathi R, Senthilnathan P, Chodon D, Sakthisekaran D. Therapeutic effect of paclitaxel and propolis on lipid peroxidation and antioxidant system in 7,12 dimethyl benz(a)anthracene-induced breast cancer in female Sprague Dawley rats. Life Sci. 2006;78(24):2820-5.

58. Vurusaner B, Poli G, Basaga H. Tumor suppressor genes and ROS: complex networks of interactions. Free Radic Biol Med. 2012;52(1):7-18.

59. Semenza GL. Hypoxia-inducible factors: coupling glucose metabolism and redox regulation with induction of the breast cancer stem cell phenotype. EMBO J. 2017;36(3):252-9. 
60. Lim YY, Quah EPL. Antioxidant properties of different cultivars of Portulaca oleracea. Food Chem. 2007;103:73440.

61. Benzie IF, Strain JJ. The ferric reducing ability of plasma (FRAP) as a measure of "antioxidant power": the FRAP assay. Anal Biochem. 1996;239:70-6.

62. Griffin SP, Bhagooli R. Measuring antioxidant potential in corals using the FRAP assay. J Exp Mar Biol Ecol. 2004;302(2):201-11.

63. Pennycooke JC, Cox SE, Stushnoff C. Relationship of cold acclimation, total phenolic content and antioxidant capacity with chilling tolerance in petunia (Petunia hybrid). Environ Exp Bot. 2005;53:225-32.

64. Dehghan G, Dolatabadi JE, Jouyban A, Zeynali KA, Ahmadi SM, Kashanian S. Spectroscopic studies on the interaction of quercetin-terbium(III) complex with calf thymus DNA. DNA Cell Biol. 2011;30(3):195-201.

65. Li H, Wang Q, Dong L, Liu C, Sun Z, Gao L, et al. Morusin suppresses breast cancer cell growth in vitro and in vivo through C/EBPß and PPARy mediated lipoapoptosis. J Exp Clin Cancer Res. 2015;34:137.

66. Deng XH, Song HY, Zhou YF, Yuan GY, Zheng FJ. Effects of quercetin on the proliferation of breast cancer cells and expression of survivin in vitro. Exp Ther Med. 2013;6(5):1155-8.

67. Roy S, Majumdar S, Singh AK, Ghosh B, Ghosh N, Manna S, et al. Synthesis, Characterization, Antioxidant Status, and Toxicity Study of Vanadium-Rutin Complex in Balb/c Mice. Biol Trace Elem Res. 2015;166(2):183-200.

68. Kaliaperumal J, Arumugam V, Namasivayam E, PravanKumar P. Evaluation of the anti-tumor and antioxidant activity of Amorphophallus Paeonifolius on DMBA induced mammary carcinoma. Int J Chem Pharm Sci. 2010;1:40-50.

69. Sinha BBP, Peterson GA, Li GC, Whitney RR. Nuclear change distribution of isotone pairs I. 31P and 32S. Phys Rev C. 1972;6:1657-63.

70. Awasthi S, Kakkar P, Viswanathan PN, Bharadwaj R. Effect of anaesthetic ether on lipid peroxidation and superoxide dismutase isozymes of young and adult rat brain. Indian J Exp Biol. 1989;27:647-9.

71. Rotruck JT, Pope AL, Ganther HE, Swanson AB, Hafeman DG, Hoekstra WG. Selenium: biochemical role as a component of glutathione peroxidase. Science. 1973;179(4073):588-90.

72. Ray RS, Ghosh B, Rana A, Chatterjee M. Suppression of cell proliferation, induction of apoptosis and cell cycle arrest: chemopreventive activity of vanadium in vivo and in vitro. Int J Cancer. 2007;120(1):13-23.

73. Hanahan D, Weinberg RA. Hallmarks of cancer: the next generation. Cell. 2011;144(5):646-74.

74. Allardyce CS, Dyson PJ. Ruthenium in medicine: current clinical uses and future prospect. Platin Met Rev. 2001;45:62-9.

75. Santamaria R, Irace C, D’Ericco G, Montesarchio D, Paduano L. Perspectives and potential application of Ruthenium based nano-carriers for cancer therapy. JPDD. 2013;1:1-4.

76. Wong RS. Apoptosis in cancer: from pathogenesis to treatment. J Exp Clin Cancer Res. 2011;30:87.

77. Fatehi Hassanabad A. Current perspectives on statins as potential anti-cancer therapeutics: clinical outcomes and underlying molecular mechanisms. Transl Lung Cancer Res. 2019;8(5):692-9.

78. Gazzerro P, Proto MC, Gangemi G, Malfitano AM, Ciaglia E, Pisanti S, et al. Pharmacological actions of statins: a critical appraisal in the management of cancer. Pharmacol Rev. 2012;64(1):102-46.

79. Paškevičiūtè $M$, Petrikaitè V. Differences of statin activity in 2D and 3D pancreatic cancer cell cultures. Drug Des Devel Ther. 2017;11:3273-80.

80. Wong WW, Clendening JW, Martirosyan A, Boutros PC, Bros C, Khosravi F, Jurisica I, Stewart AK, Bergsagel PL, Penn LZ. Determinants of sensitivity to lovastatin-induced apoptosis in multiple myeloma. Mol Cancer Ther. 
2007;6(6):1886-97.

81. Vaklavas C, Chatzizisis YS, Tsimberidou AM. Common cardiovascular medications in cancer therapeutics. Pharmacol Ther. 2011;130(2):177-90.

82. George JM. The synucleins. Genome Biol. 2002;3(1):REVIEWS3002.

83. Singh VK, Zhou Y, Marsh JA, Uversky VN, Forman-Kay JD, Liu J, et al. Synuclein-gamma targeting peptide inhibitor that enhances sensitivity of breast cancer cells to antimicrotubule drugs. Cancer Res. 2007;67(2):626-33.

84. Muthurajan T, Rammanohar P, Rajendran NP, Sethuraman S, Krishnan UM. Evaluation of a quercetin-gadolinium complex as an efficient positive contrast enhancer for magnetic resonance imaging. RSC Advances.

2015;5:86967-79.

85. Zotano AG, Mayer IA, Arteaga CL. PI3K/AKT/mTOR: role in breast cancer progression, drug resistance, and treatment. Cancer Metastasis Rev. 2016;35:515-24.

86. Fruman DA, Chiu H, Hopkins BD, Bagrodia S, Cantley LC, Abraham RT. The PI3K Pathway in Human Disease. Cell. 2017;170(4):605-35.

87. Laplante MD, Sabatini M. mTOR signaling in growth control and disease. Cell. 2012;149:274-93.

88. Engelman JA. Targeting PI3K signalling in cancer: opportunities, challenges and limitations. Nat Rev Cancer. 2009;9:550-62.

89. Lien EC, Dibble CC, Toker A. PI3K signaling in cancer: beyond AKT. Curr Opin Cell Biol. 2017;45:62-71.

90. Martini M, Santis MCD, Braccini L, Gulluni F, Hirsch E. PI3K/AKT signaling pathway and cancer: an updated review. Ann Med. 2014;46:372-83.

91. Fruman DA, Rommel C. PI3K and cancer: Lessons, challenges and opportunities. Nat Rev Drug Discov. 2014;13:140-56.

92. Davis NM, Sokolosky M, Stadelman K, Abrams SL, Libra M, Candido S, et al. Deregulation of the EGFR/PI3K/PTEN/Akt/mTORC1 pathway in breast cancer: possibilities for therapeutic intervention. Oncotarget. 2014;5(13):4603-50.

93. Balakrishnan S, Mukherjee S, Das S, Bhat FA, Raja Singh P, Patra CR, et al. Gold nanoparticles-conjugated quercetin induces apoptosis via inhibition of EGFR/PI3K/Akt-mediated pathway in breast cancer cell lines (MCF-7 and MDA-MB-231). Cell Biochem Funct. 2017;35(4):217-31.

94. Mitsudomi T, Yatabe Y. Epidermal growth factor receptor in relation to tumor development: EGFR gene and cancer. FEBS J. 2010;277(2):301-8.

95. Huang L, Wong CC, Mackenzie GG, Sun Y, Cheng KW, Vrankova K, et al. Phospho-aspirin (MDC-22) inhibits breast cancer in preclinical animal models: an effect mediated by EGFR inhibition, p53 acetylation and oxidative stress. BMC Cancer. 2014;14:141.

96. Schladt TD, Schneider K, Schild H, Tremel W. Synthesis and bio-functionalization of magnetic nanoparticles for medical diagnosis and treatment. Dalton Trans. 2011;40(24):6315-43.

97. Ding Y, Liu J, Wang H, Shen G, Yu R. A piezoelectric immunosensor for the detection of alpha-fetoprotein using an interface of gold / hydroxyapatite hybrid nanomaterial. Biomaterials. 2007;28:2147-2154.

98. Sperling RA, Rivera P, Gil P, Zhang F, Zanella M, Parak WJ. Biological applications of gold nanoparticles. Chem Soc Rev. 2008;37:1896-981.

99. Ferrara N, Alitalo K. Clinical applications of angiogenic growth factors and their inhibitors. Nat Med. 1999;5:1359-64. 
100. Kumar BNP, Puvvada N, Rajput S, Sarkar S, Mahto MK, Yallapu MM, et al. Targeting of EGFR, VEGFR2, and Akt by Engineered Dual Drug Encapsulated Mesoporous Silica-Gold Nanoclusters Sensitizes Tamoxifen-Resistant Breast Cancer. Mol Pharm. 2018;15(7):2698-713.

101. Hassan M, Watari H, AbuAlmaaty A, Ohba Y, Sakuragi N. Apoptosis and molecular targeting therapy in cancer. Biomed Res Int. 2014; 2014:150845.

102. Hajrezaie M, Hassandarvish P, Moghadamtousi SZ, Gwaram NS, Golbabapour S, Najihussien A. et.al. Chemopreventive evaluation of a Schiff base derived copper (II) complex against azoxymethane-induced colorectal cancer in rats. Plos One. 2014;9:e91246.

103. Kastenhuber ER, Lowe SW. Putting p53 in Context. Cell. 2017;170:1062-78.

104. Fischer M. Census and evaluation of p53 target genes. Oncogene. 2017;36:3943-56.

105. Hientz K, Mohr A, Guha DB, Efferth T. The role of p53 in cancer drug resistance and targeted chemotherapy. Oncotarget. 2017;8:8921-46.

106. Ventura A, Kirsch DG, McLaughlin ME, Tuveson DA, Grimm J, Lintault L, et al. Restoration of p53 function leads to tumour regression in vivo. Nature. 2007;445(7128):661-5.

107. Miyashita T, Reed JC. Tumor-Suppressor P53 is a direct transcriptional activator of the human bax gene. Cell. 1995;80:293-9.

108. Jiang P, Du WJ, Heese K, Wu M. The bad guy cooperates with good cop p53: Bad is transcriptionally up-regulated by p53 and forms a bad/p53 complex at the mitochondria to induce apoptosis. Mol Cell Biol. 2006;26:9071-82.

109. Nam GH, Jo KJ, Park YS, Kawk HW, Kim SY, Kim YM. In vitro and in vivo Induction of p53-dependent apoptosis by extract of euryale ferox salisb in A549 human caucasian lung carcinoma cancer cells is mediated through Akt signaling pathway. Front Oncol. 2019;9:406.

110. Balduyck M, Zerimech F, Gouyer V, Lemaire R, Hemon B, Grard G, et al. Specific expression of matrix metalloproteinases 1, 3, 9 and 13 associated with invasiveness of breast cancer cells in vitro. Clin Exp Metastasis. 2000;18:171-8.

111. Yousef EM, Tahir MR, St-Pierre Y, Gaboury LA. MMP-9 expression varies according to molecular subtypes of breast cancer. BMC Cancer. 2014;14:609.

112. Cao D, Polyak K, Halushka MK, Nassar H, Kouprina N, lacobuzio-Donahue C, et al. Serial analysis of gene expression of lobular carcinoma in situ identifies down regulation of claudin 4 and overexpression of matrix metalloproteinase 9. Breast Cancer Res. 2008;10(5):R91.

113. Panieri E, Santoro MM. ROS homeostasis and metabolism: A dangerous liason in cancer cells. Cell Death Dis. 2016;7:e2253.

114. Giorgio M, Trinei M, Migliaccio E,. Pelicci PG. Hydrogen peroxide: a metabolic byproduct or a common mediator of ageing signals? Nat Rev Mol Cell Biol. 2007;8:722-8.

115. Khan MA, Chen HC, Wan XX, Tania M, Xu AH, Chen FZ, et al. Regulatory effects of resveratrol on antioxidant enzymes: a mechanism of growth inhibition and apoptosis induction in cancer cells. Mol Cells. 2013;35(3):21925.

116. Suciu C, Muresan A, Cornea R, Suciu O, Dema A, Raica M. Semi-automated evaluation of Ki-67 index in invasive ductal carcinoma of the breast. Oncol Lett. 2014;7:107-14.

117. Dowsett M, Nielsen TO, A'Hern R, Bartlett J, Coombes RC, Cuzick J, et al. Assessment of Ki67 in breast cancer: Recommendation from the international Ki67 in breast cancer working group. J Natl Cancer Inst. 2011;103:165664.

Page 32/41 
118. Yerushalmi R, Woods R, Ravdin PM, Hayes MM, Gelmon KA. Ki67 in breast cancer: prognostic and predictive potential. Lancet Oncol. 2010;11:174-83.

119. de Azambuja E, Cardoso F, de Castro G Jr, Colozza M, Mano MS, Durbecq V, et al. Ki-67 as prognostic marker in early breast cancer: A meta-analysis of published studies involving 12,155 patients. Br J Cancer. 2007;96:150413.

\section{Figures}

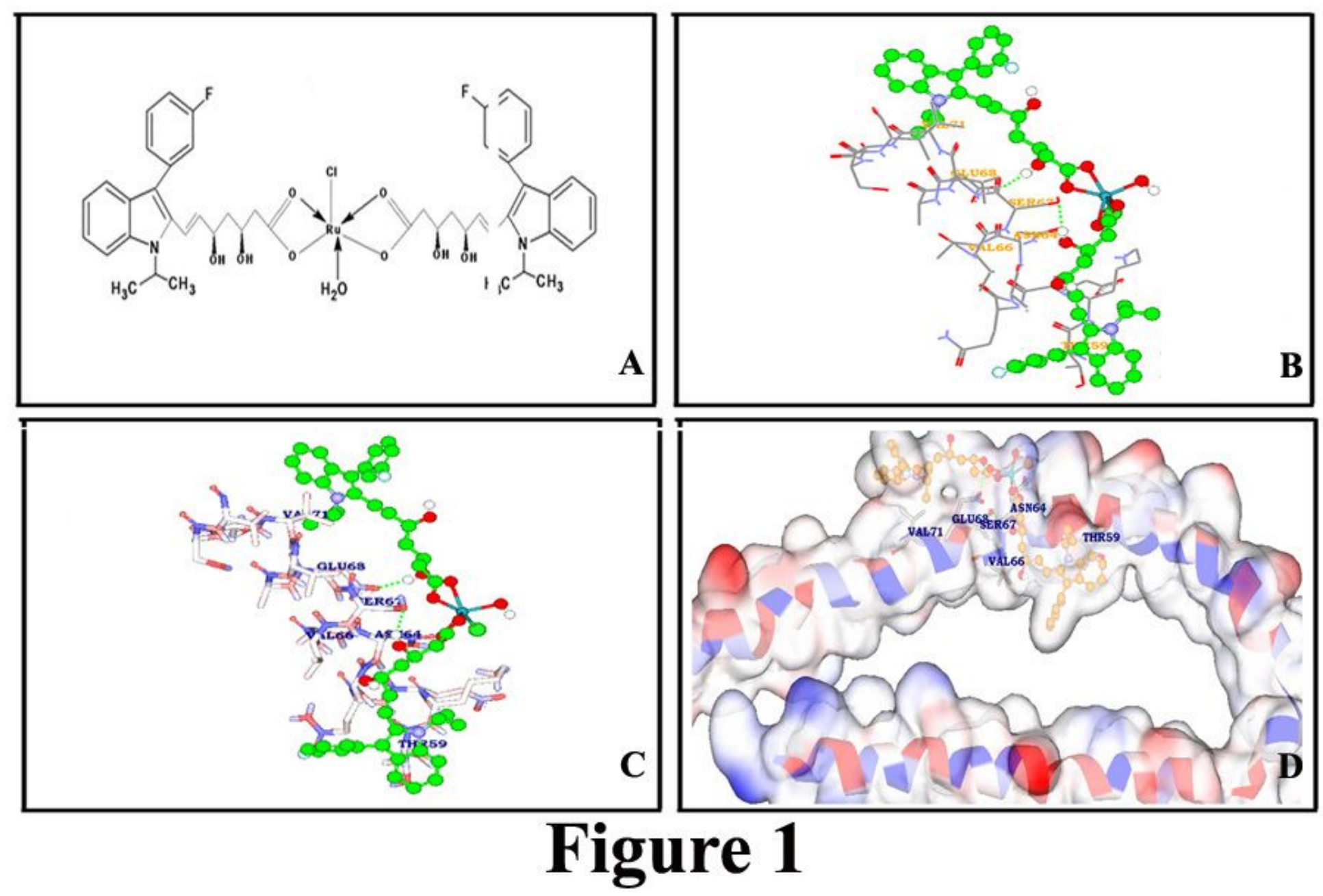

Figure 1

(A) The possible structure of ruthenium-fluvastatin complex. (B) (C) and (D) Receptor-ligand Hydrogen bonding interactions of Ru-flu with active site residues of Gamma-Synuclein. 

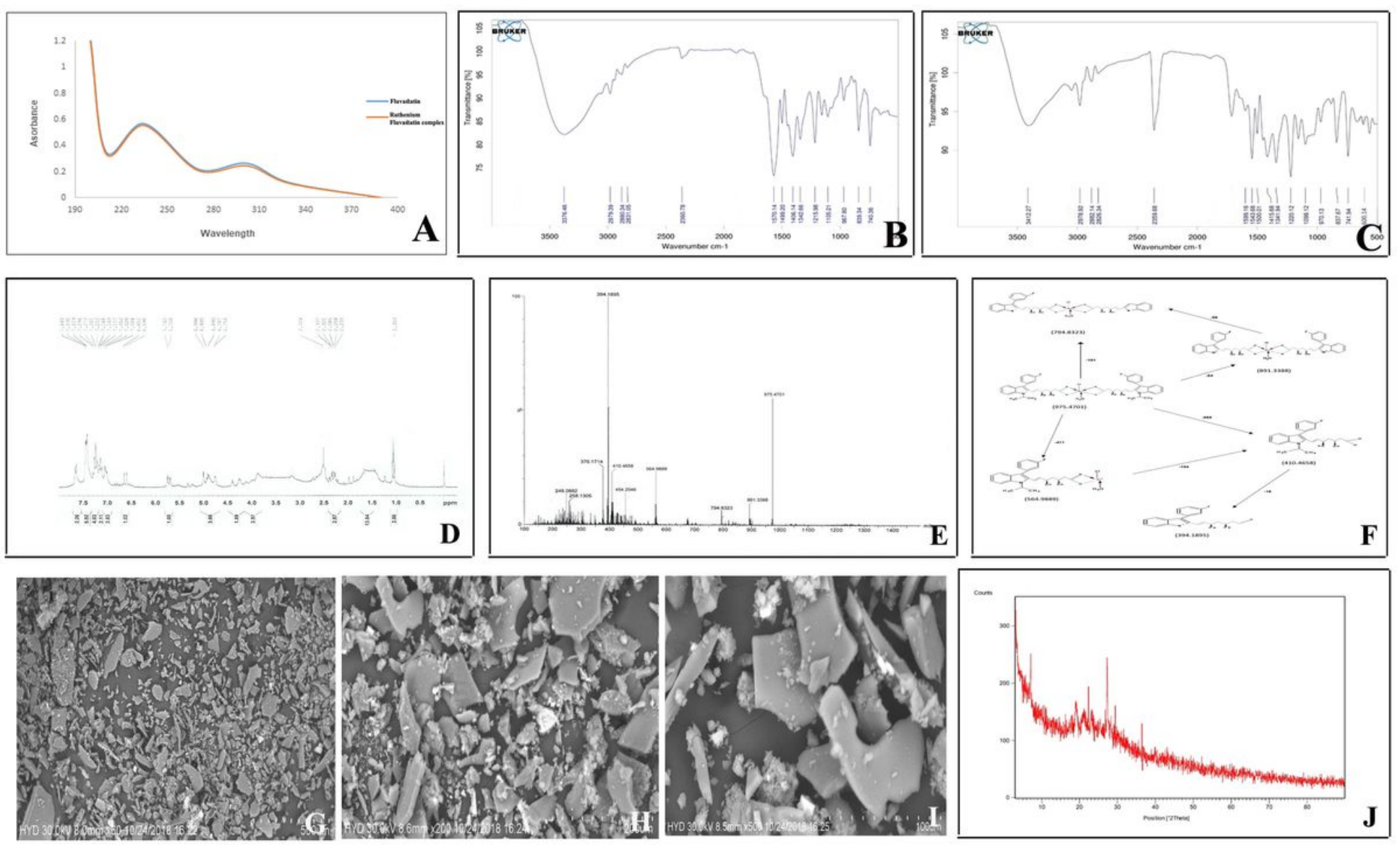

Figure 2

Figure 2

(A) UV-Visible spectra of fluvastatin and ruthenium-fluvastatin complex (B) FTIR spectra of fluvastatin (C) FTIR spectra of ruthenium-fluvastatin complex (D) NMR spectra of ruthenium-fluvastatin complex (E) Mass spectroscopy of ruthenium- fluvastatin complex (F) possible fragmentations mechanism ruthenium- fluvastatin molecule. Scanning electron microscopy (SEM) of the complex at (G) $200 \mu \mathrm{m}(\mathrm{H}) 100 \mu \mathrm{m}$ and (I) $50 \mu \mathrm{m}$. (J) X-ray diffractogram of ruthenium-fluvastatin complex. 

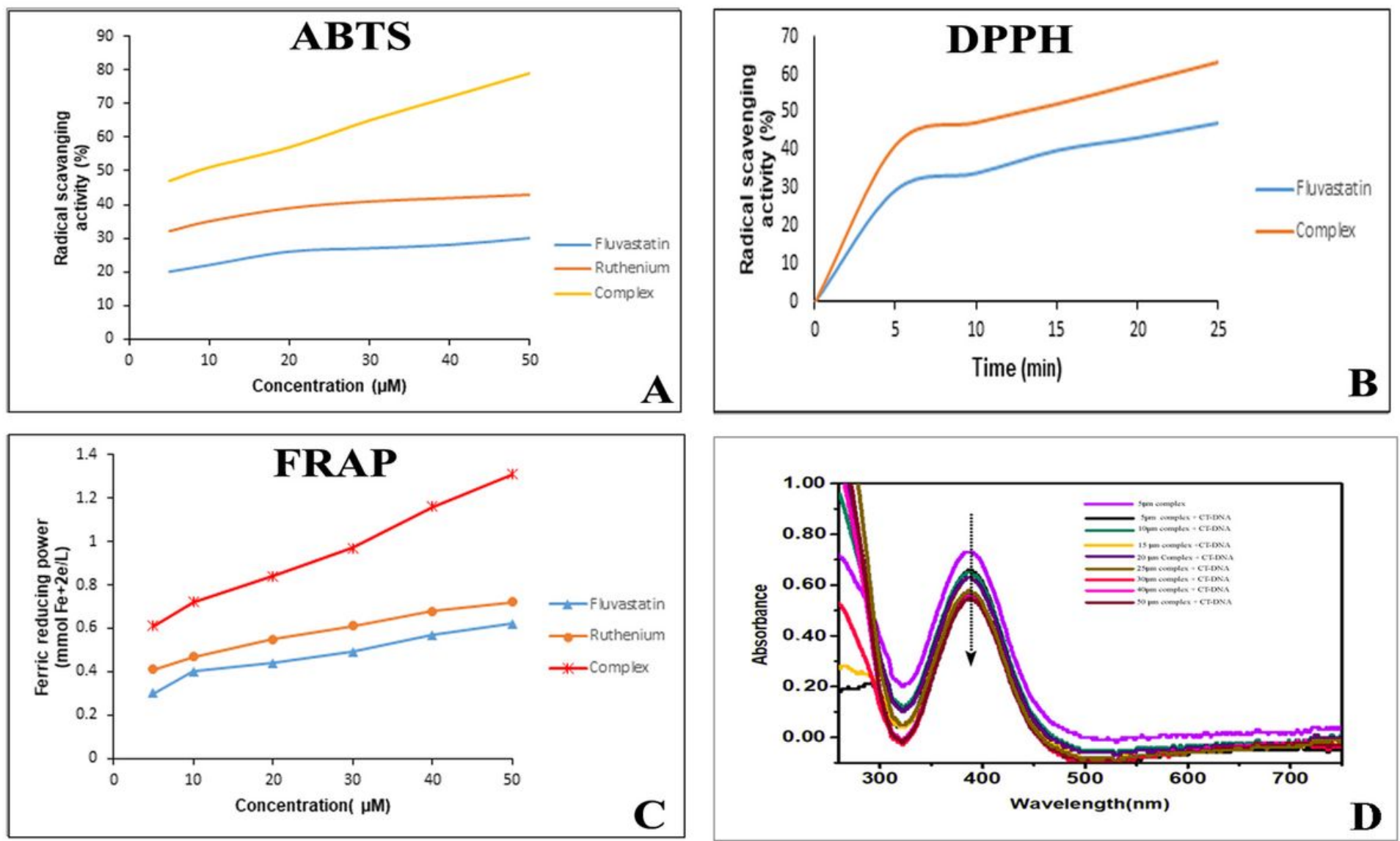

\section{Figure 3}

Figure 3

Measurement of anti-oxidant activity of the complex. (A) Anti-oxidant activity of ruthenium-fluvastatin complex by ABTS method, (B) DPPH method, (C) FRAP method, (D) Absorbance spectra of CT-DNA in the presence of rutheniumfluvastatin complex. 

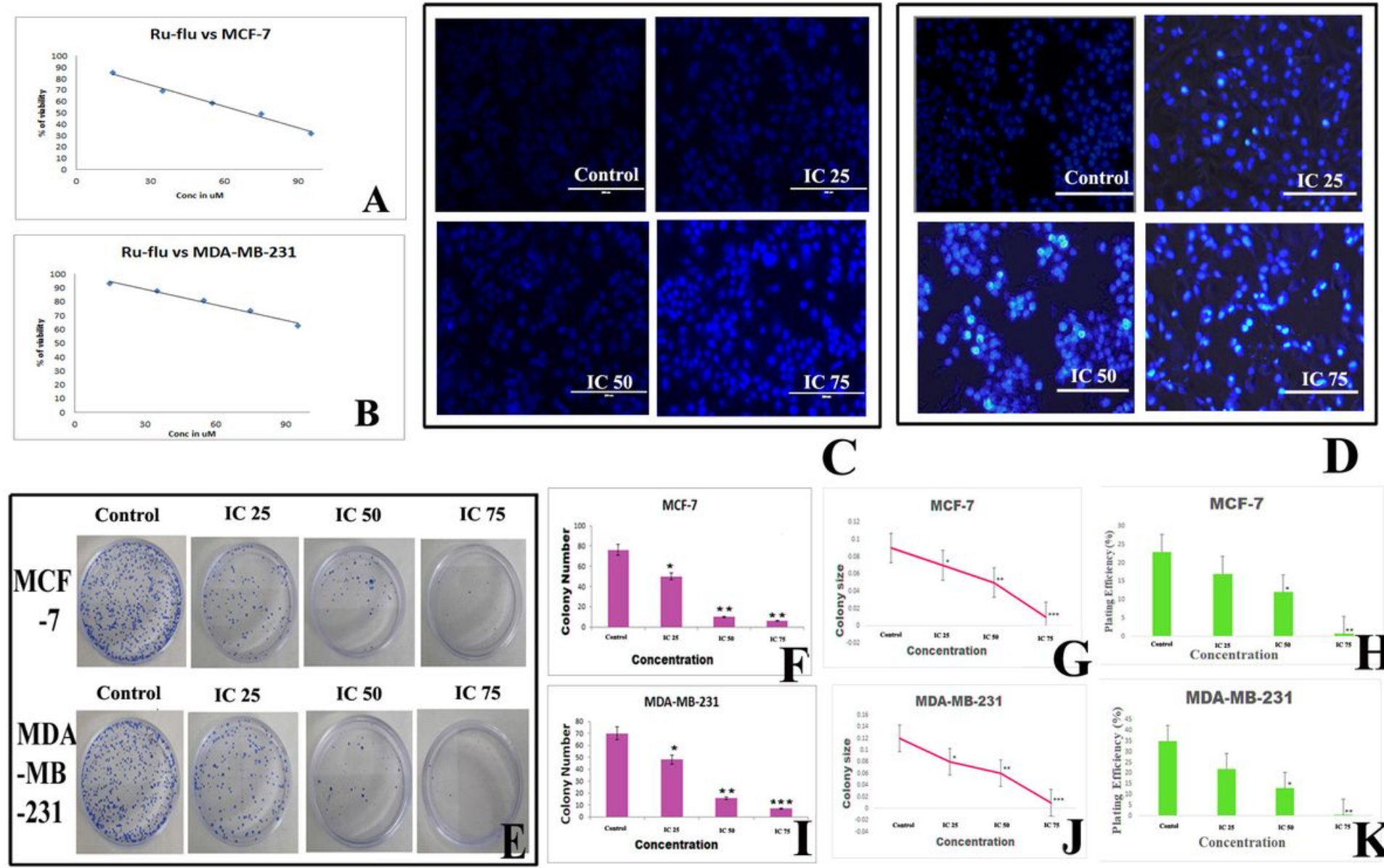

D

\section{Figure 4}

Figure 4

Effects of ruthenium-fluvastatin complex on cell viability of (A) MCF-7 cells and (B) MDA-MB-231 cells at 24 hours. (C) DAPI stained MCF-7 cells after 24 hours of treatment with ruthenium-fluvastatin complex, (D) DAPI stained MDA-MB231 cells after 24 hours of treatment with ruthenium-fluvastatin complex, (E) Clonogenic assay of MCF-7 and MDAMB-231cells after 24 hours of treatment with ruthenium-fluvastatin complex, $(F)$ Quantification of colony number for MCF-7 cells, (G) Quantification of colony size of clonogenic assay of MCF-7 cells (H) Plating efficiency for clonogenic assay of MCF-7 cells, (I) Quantification of colony number for MDA-MB-231 cells (J) Quantification of colony size for MDA-MB-231 cells (K) Plate efficiency for clonogenic assay of MDA-MB-231 cells.Quantification of colony number and size was performed using Image $\mathrm{J}$ public domain software. Data represent means \pm SD from three different experiments intriplicate. The results were compared using ANOVA, followed by a Tukey's post-hoc analysis. Asterisks represent ${ }^{*} p<0.05,{ }^{*} p<0.01,{ }^{* \star} p<0.001$ as compared to carcinogen control. 

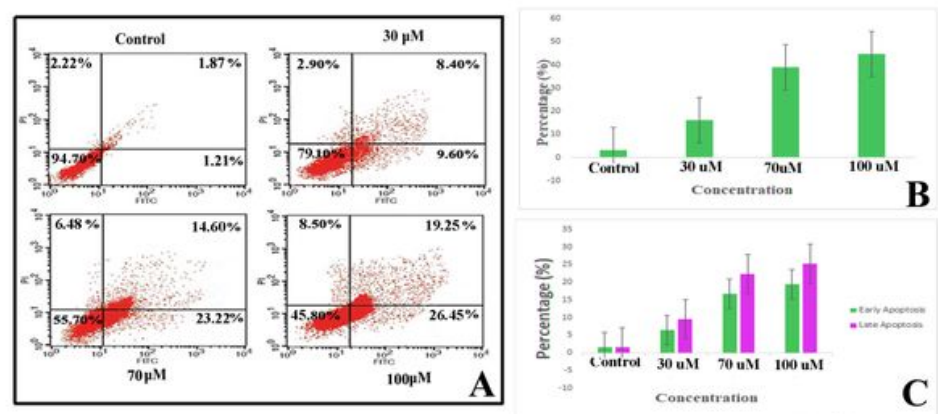

C
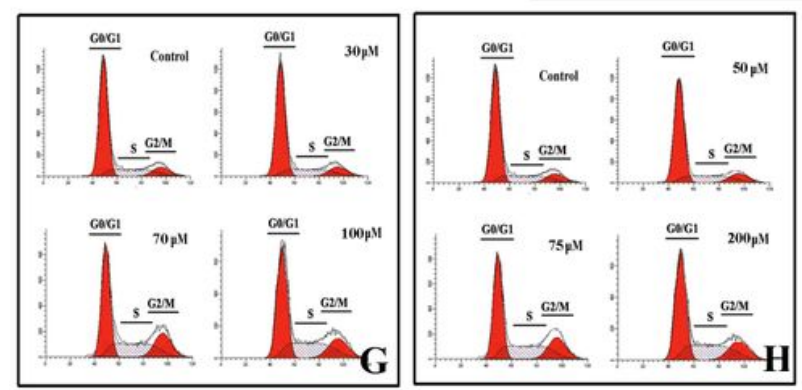

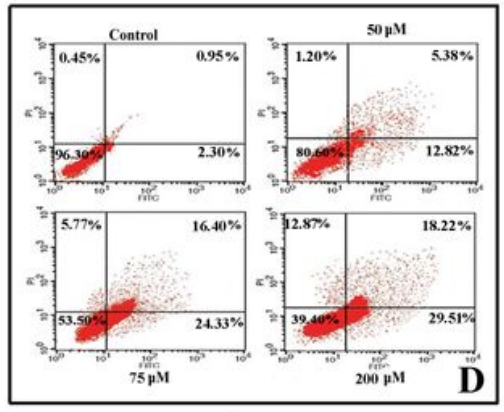

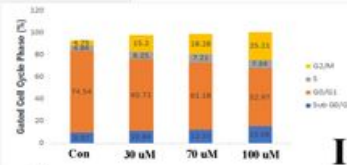

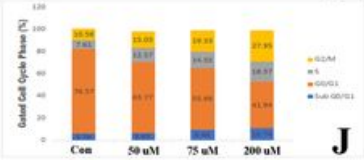

Figure 5

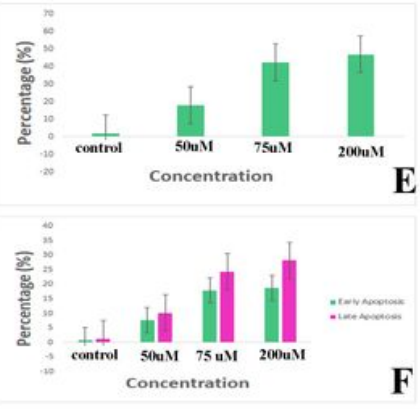

$\mathbf{E}$

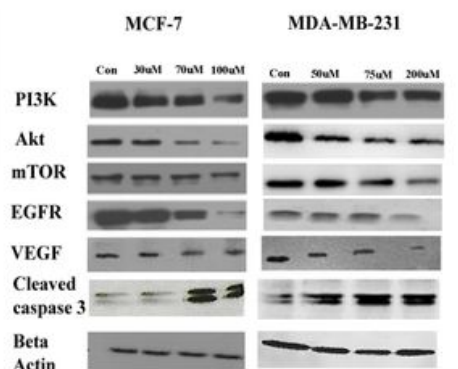

M

Figure 5

(A) Detection of apoptosis in MCF-7 cells by Flow cytometry after treatment with ruthenium-fluvastatin complex. (B) Percentage of apoptotic cells versus concentration in MCF-7 cells, (C) Percentage of apoptotic cells in early and late apoptosis stage in MCF-7 cells, (D) Detection of apoptosis in MDA-MB-231 cells by Flow cytometry after treatment with ruthenium-fluvastatin complex, (E) Percentage of apoptotic cells versus concentration in MDA-MB-231 cells, (F) Percentage of apoptotic cells in early and late apoptosis stage in MDA-MB-231 cells, $(G)$ Analysis of cell cycle phase distribution of MCF-7 cells after the treatment with ruthenium-fluvastatin complex, $(\mathrm{H})$ Analysis of cell cycle phase distribution of MDA-MB-231cells after the treatment with ruthenium-fluvastatin complex, (I) Quantitative of distribution of MCF-7 cells in different phases of cell cycle, $(\mathrm{J})$ Quantitative of distribution of MDA-MB-231cells in different phases of cell cycle, $(\mathrm{K})$ Expression of caspase-3 proteins in MCF-7 cells after 24 hours of treatment with rutheniumfluvastatin complex, $(\mathrm{L})$ Expression of caspase-3 proteins in MDA-MB-231cells after 24 hours of treatment with ruthenium-fluvastatin complex, (M) Western blot analysis of expressions of PI3K, Akt, mTOR, EGFR, VEGF and cleaved caspase-3 in MCF-7 and MDA-MB-231 cells. 


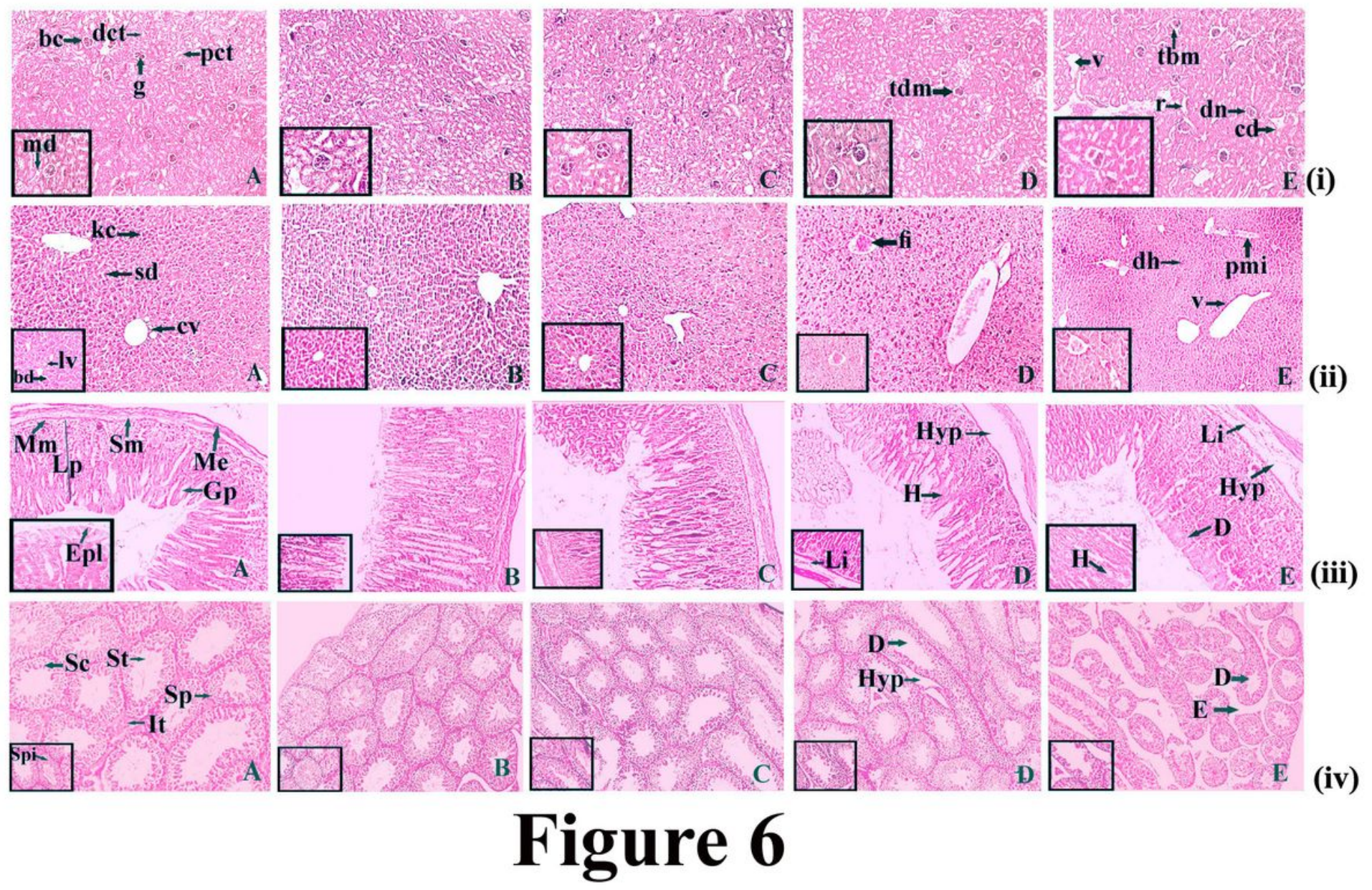

Figure 6

[i] Histopathological representation of kidney of Balb/c mice. (A) Normal tissue showing (g) glomerulus, Bowman's capsule (bc), Macula densa (md), Proximal convoluted tubule (pct), Distal convoluted tubule (dct), (B) kidney tissue exposed to $25 \mathrm{mg} / \mathrm{kg}$ complex kidney tissue, (C) kidney tissue exposed to $50 \mathrm{mg} / \mathrm{kg}$ complex, (D) kidney tissue exposed to $100 \mathrm{mg} / \mathrm{kg}$ complex, (E) exposed to $200 \mathrm{mg} / \mathrm{kg}$ complex showing thickening of capsular membrane (tbm), ruptures (r), desquamated nuclei (dn), vacuolization, [ii] Histopathological representation of Liver of Balb/c mice, (A) Normal control showing the Central vein (cv), Bile duct (bd), Sinusoidal dilation (sd), Kupffer cell (kc), Lymph vessel (lv), (B) \& (C) kidney tissue exposed to $25 \mathrm{mg} / \mathrm{kg}$ and $50 \mathrm{mg} / \mathrm{kg}$ of complex, (D) \& (E) kidney tissue exposed to 100 \& $200 \mathrm{mg} / \mathrm{kg}$ complex showing periportal mononuclear infiltrates (pmi), degeneration of hepatocytes (dh), focal inflammation (fi), [iii] Histopathological representation of stomach of Balb/c mice, (A) Normal control showing Muscularis externa (me), Submucosa (sm), Muscularis mucosa (mm), Lamina propia (Ip), Gastric pit (gp), epithelial lining (epl), (B) \& (C) Stomach tissue exposed to $25 \mathrm{mg} / \mathrm{kg}$ and $50 \mathrm{mg} / \mathrm{kg}$ of complex, (D) \& (E) Stomach tissue exposed to 100 \& 200 mg/kg complex showing Hemorrhages (h) between villus, Hyperplasia (hyp), leukocyte infiltration ( $\mathrm{Li}$ ), [iv] Histopathological representation of testis of Balb/c mice, (A) Normal control showing Sertoli cell (sc), Spermatogonia (Sp), Seminiferous tubule (St), Interstitial tissues (It) is seen within the tubular lumen, (B) \& (C) testis exposed to $25 \mathrm{mg} / \mathrm{kg}$ and $50 \mathrm{mg} / \mathrm{kg}$ of complex, (D) \& (E) testis exposed to 100 \& $200 \mathrm{mg} / \mathrm{kg}$ complex showing Edema in interstitial tissue (E), Degeneration of seminiferous tubule (D) and hyperplasia (Hyp). (H\&E) 10X magnification [inset 40X] 

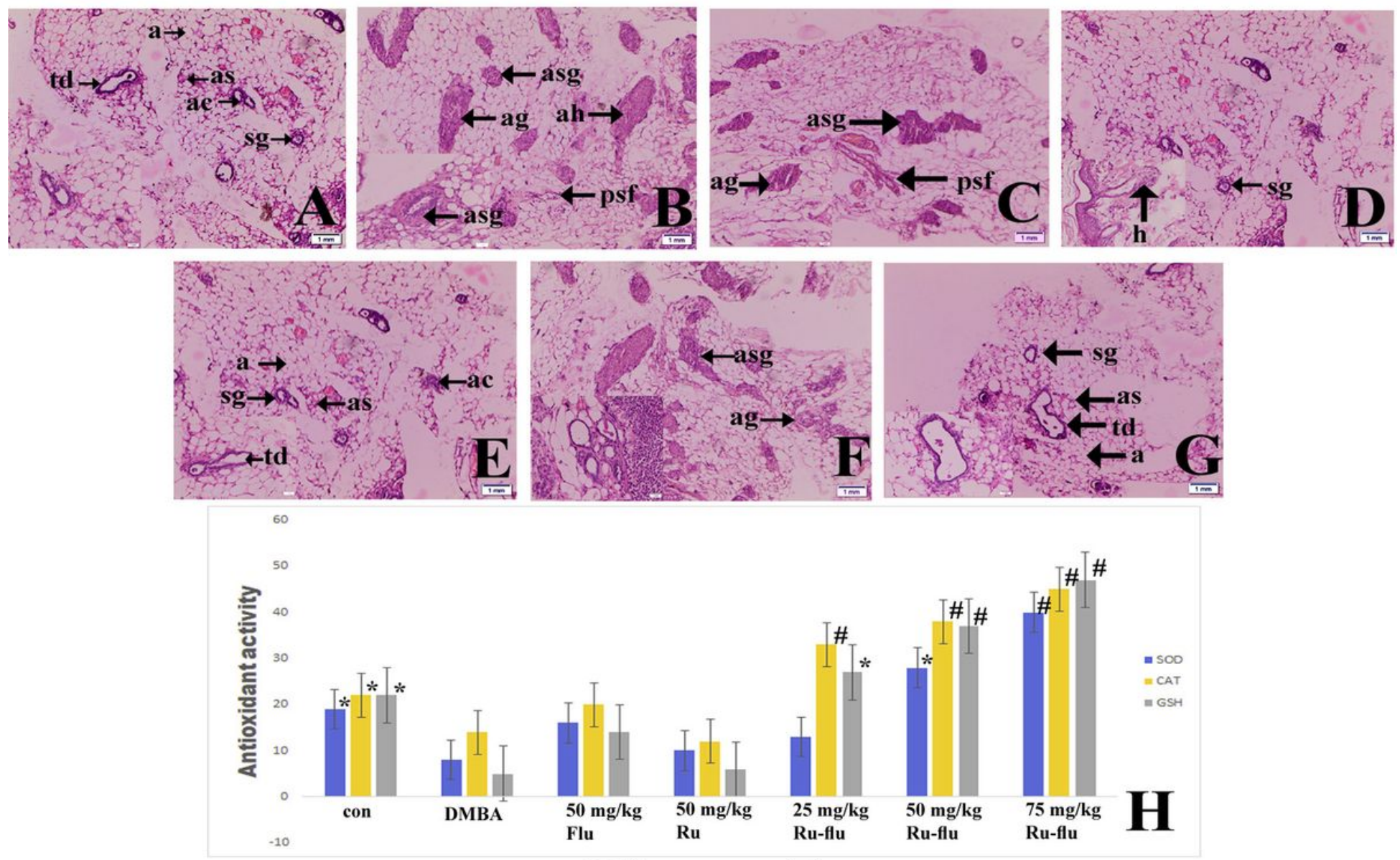

Figure 7

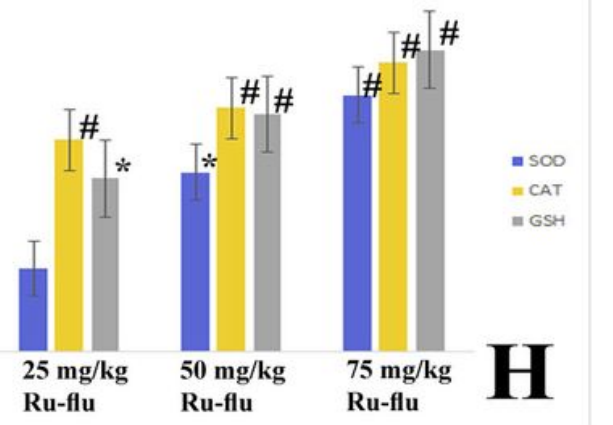

\section{Figure 7}

(A) Histological appearance of mammary tissue of normal control showing Terminal duct lobular units (td), alveoli (a), alveolar septa (sg), Acinus(ac), serous gland (sg), (B) DMBA control shows atrophy of glands with periductal stromal fibrosis and fatty tissue (psf), atrophy of glands (ag) with surrounding fatty tissue, atrophy of serous glands (asg) with surrounding stromal fibrosis, Atypical hyperplasia (ah), (C) Mammary tissue of DMBA induced group treated with $25 \mathrm{mg} / \mathrm{kg}$ ruthenium-fluvastatin complex showing atrophy of serous glands (asg), atrophy of glands (ag) and periductal stromal fibrosis and fatty tissue (psf), (D) Mammary tissue of DMBA induced group treated with $50 \mathrm{mg} / \mathrm{kg}$ ruthenium-fluvastatin complex showing hyperplasia of serous and mucinous glands (h), (E) Mammary tissue of DMBA induced group treated with $75 \mathrm{mg} / \mathrm{kg}$ ruthenium-fluvastatin complex having almost normal architecture, $(\mathrm{F})$ Mammary tissue of DMBA induced group treated with $50 \mathrm{mg} / \mathrm{kg}$ ruthenium, (G) Mammary tissue of DMBA induced group treated with $50 \mathrm{mg} / \mathrm{kg}$ fluvastatin, $(\mathrm{H})$ Effect of ruthenium-fluvastatin complex on in-vivo antioxidant enzymes SOD (superoxide dismutase) and CAT (catalase), (glutathione) GST. * $p<0.05$ as compared to the carcinogen control, \# p<0.01 as compared to the ruthenium, fluvastatin, Ruthenium-fluvastatin 25, 50 and $100 \mathrm{mg} / \mathrm{kg}$. 

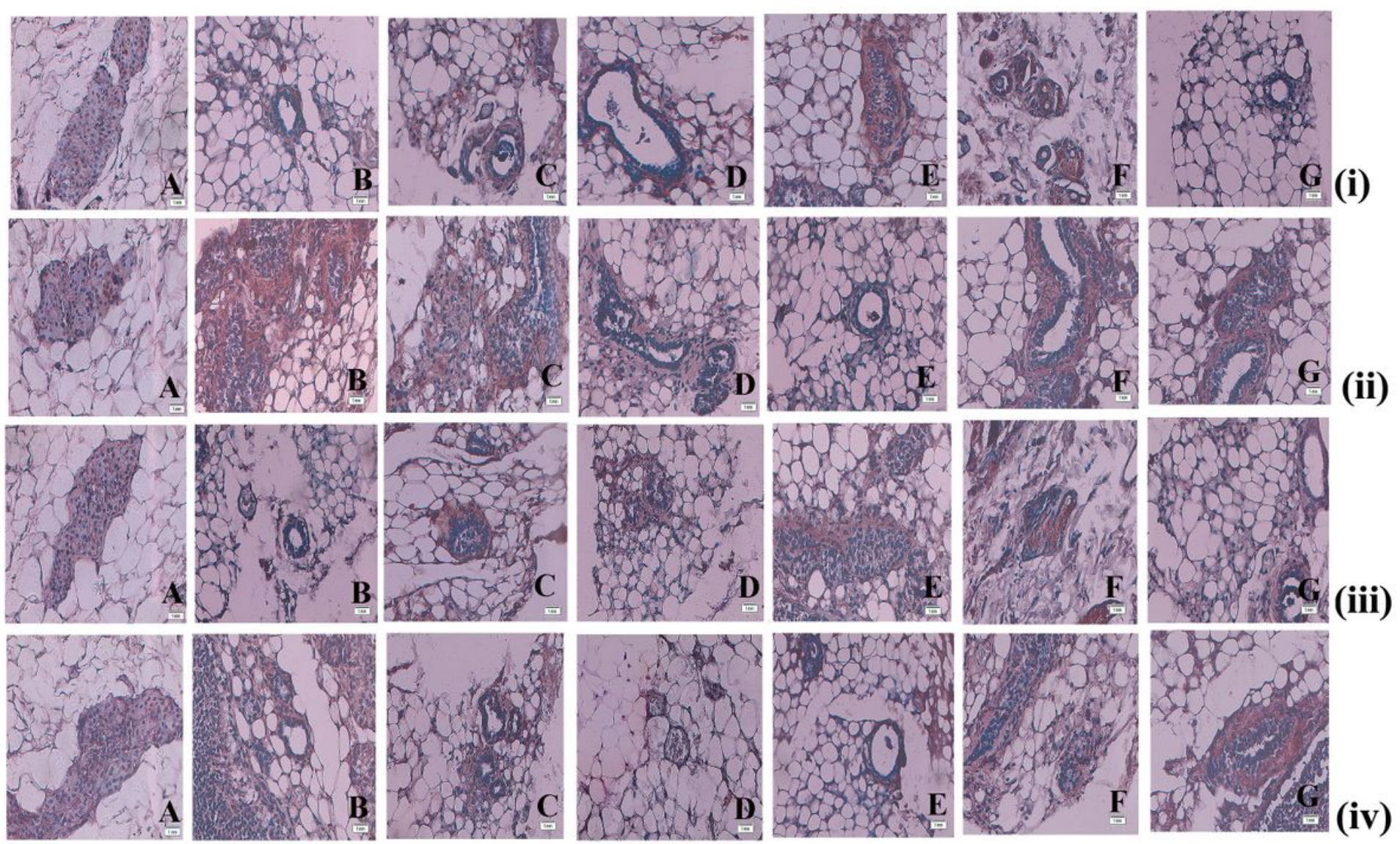

Figure 8

Figure 8

The immunohistochemical analysis of the [i] p53, [ii] Bcl2, [iii] Bax and [vi] MMP9 expressions in the mammary tissues of different groups of rats (A) the normal control (B) carcinogen control, (C) $25 \mathrm{mg} / \mathrm{kg}$ of complex treated, (D) \& (E) 50 and $100 \mathrm{mg} / \mathrm{kg}$ complex treated. (F) $50 \mathrm{mg} / \mathrm{kg}$ fluvastatin treated animals (G) $50 \mathrm{mg} / \mathrm{kg}$ ruthenium treated animals. All images at $40 \mathrm{X}$.
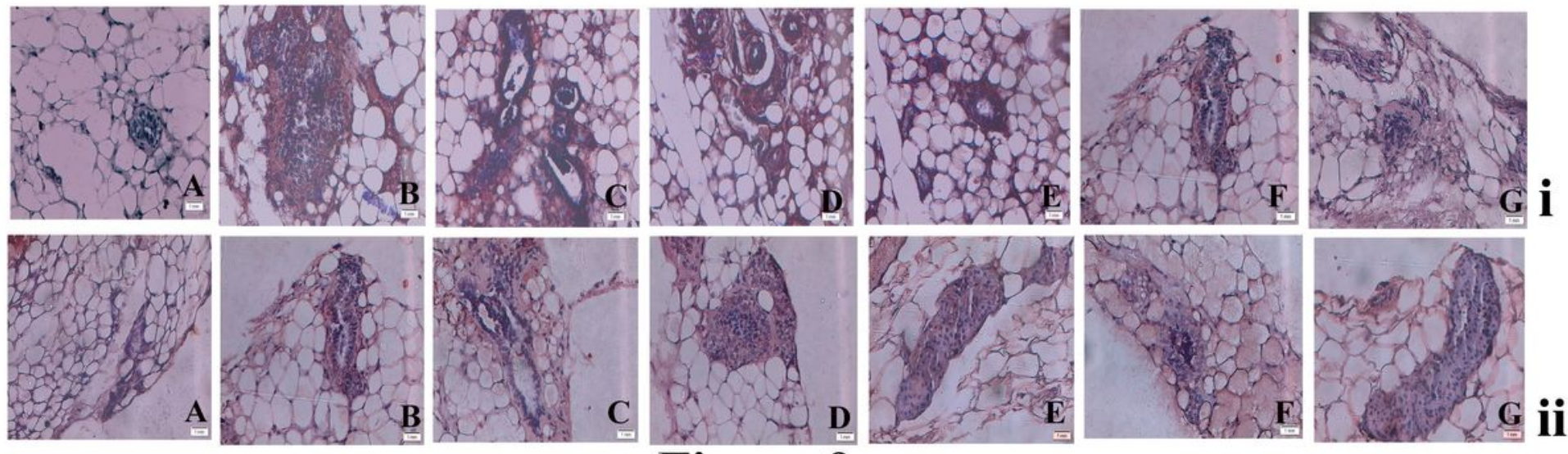

Figure 9

Figure 9 
[i] The immunohistochemical analysis of expression of Ki-67 of different group of rats (A) the normal control, (B) carcinogen control, (C) $25 \mathrm{mg} / \mathrm{kg}$ of complex treated, (D) \& (E) 50 and $100 \mathrm{mg} / \mathrm{kg}$ complex treated. (F) $50 \mathrm{mg} / \mathrm{kg}$ fluvastatin treated animals $(\mathrm{G}) 50 \mathrm{mg} / \mathrm{kg}$ ruthenium treated animals. All images at 40X. [ii] TUNEL assay of apoptotic, (A) the normal control, (B) carcinogen control, (C) $25 \mathrm{mg} / \mathrm{kg}$ of complex treated, (D) \& (E) 50 and $100 \mathrm{mg} / \mathrm{kg}$ complex treated. (F) $50 \mathrm{mg} / \mathrm{kg}$ fluvastatin treated animals (G) $50 \mathrm{mg} / \mathrm{kg}$ ruthenium treated animals. All images at 40X. 